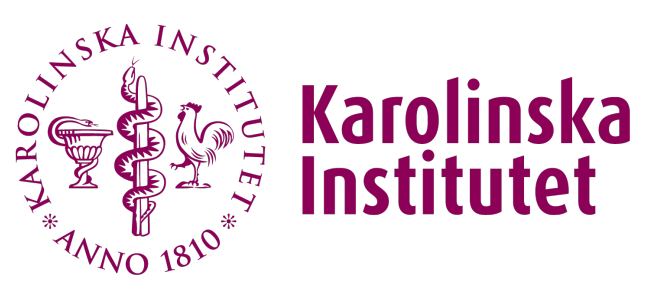

Karolinska Institutet

http://openarchive.ki.se

This is a Peer Reviewed Published version of the following article, accepted for publication in Circulation.

\title{
Identification of a danger-associated peptide from apolipoprotein B100 (ApoBDS-1) that triggers innate proatherogenic responses
}

Yan, Zhong-qun; Ketelhuth, Daniel F J; Rios, Francisco J O; Wang, Yajuan; Liu, Huiqing; Johansson, Maria E; Fredrikson, Gunilla N; Hedin, Ulf; Gidlund, Magnus; Nilsson, Jan; Hansson, Göran K

Circulation. 2011 Nov 29;124(22):2433-43, 1-7.

American Heart Association

http://doi.org/10.1161/CIRCULATIONAHA.111.051599

http://hdl.handle.net/10616/41400

If not otherwise stated by the Publisher's Terms and conditions, the manuscript is deposited under the terms of the Creative Commons Attribution-NonCommercial-NoDerivatives License (http://creativecommons.org/licenses/by-nc-nd/4.0/), which permits non-commercial re-use, distribution, and reproduction in any medium, provided the original work is properly cited, and is not altered, transformed, or built upon in any way. 


\section{Circulation}

\section{Identification of a Danger-Associated Peptide From Apolipoprotein B100 (ApoBDS-1) That Triggers Innate Proatherogenic Responses \\ Daniel F.J. Ketelhuth, Francisco J.O. Rios, Yajuan Wang, Huiqing Liu, Maria E. Johansson, Gunilla N. Fredrikson, Ulf Hedin, Magnus Gidlund, Jan Nilsson, Göran K. Hansson and Zhong-qun Yan}

Circulation. 2011;124:2433-2443; originally published online November 7, 2011; doi: 10.1161/CIRCULATIONAHA.111.051599

Circulation is published by the American Heart Association, 7272 Greenville Avenue, Dallas, TX 75231 Copyright $\odot 2011$ American Heart Association, Inc. All rights reserved.

Print ISSN: 0009-7322. Online ISSN: 1524-4539

The online version of this article, along with updated information and services, is located on the World Wide Web at:

http://circ.ahajournals.org/content/124/22/2433

Data Supplement (unedited) at:

http://circ.ahajournals.org/content/suppl/2011/11/04/CIRCULATIONAHA.111.051599.DC1.html

Permissions: Requests for permissions to reproduce figures, tables, or portions of articles originally published in Circulation can be obtained via RightsLink, a service of the Copyright Clearance Center, not the Editorial Office. Once the online version of the published article for which permission is being requested is located, click Request Permissions in the middle column of the Web page under Services. Further information about this process is available in the Permissions and Rights Question and Answer document.

Reprints: Information about reprints can be found online at: http://www.lww.com/reprints

Subscriptions: Information about subscribing to Circulation is online at: http://circ.ahajournals.org//subscriptions/ 


\title{
Identification of a Danger-Associated Peptide From Apolipoprotein B100 (ApoBDS-1) That Triggers Innate Proatherogenic Responses
}

\author{
Daniel F.J. Ketelhuth, PhD*; Francisco J.O. Rios, PhD*; Yajuan Wang, MD; Huiqing Liu, PhD; \\ Maria E. Johansson, PhD; Gunilla N. Fredrikson, PhD; Ulf Hedin, MD, PhD; Magnus Gidlund, PhD; \\ Jan Nilsson, MD, PhD; Göran K. Hansson, MD, PhD; Zhong-qun Yan, MD, PhD
}

Background - Subendothelial deposited low-density lipoprotein particles are a known inflammatory factor in atherosclerosis. However, the causal components derived from low-density lipoprotein are still poorly defined. Apolipoprotein B100 (ApoB100) is the unexchangeable protein component of low-density lipoprotein, and the progression of atherosclerosis is associated with immune responses to ApoB100-derived peptides. In this study, we analyzed the proinflammatory activity of ApoB100 peptides in atherosclerosis.

Methods and Results - By screening a peptide library of ApoB100, we identified a distinct native peptide referred to as ApoB100 danger-associated signal 1 (ApoBDS-1), which shows sequence-specific bioactivity in stimulation of interleukin-8, CCL2, and interleukin-6. ApoBDS-1 activates mitogen-activated protein kinase and calcium signaling, thereby effecting the expression of interleukin-8 in innate immune cells. Ex vivo stimulation of carotid plaques with ApoBDS-1 enhances interleukin-8 and prostaglandin $\mathrm{E}_{2}$ release. Furthermore, we demonstrated that ApoBDS-1positive peptide fragments are present in atherosclerotic lesions using immunoassays and that low-molecular-weight fractions isolated from plaque show ApoBDS-1 activity inducing interleukin-8 production.

Conclusions-Our data show that ApoBDS-1 is a previously unrecognized peptide with robust proinflammatory activity, contributing to the disease-promoting effects of low-density lipoprotein in the pathogenesis of atherosclerosis.

(Circulation. 2011;124:2433-2443.)

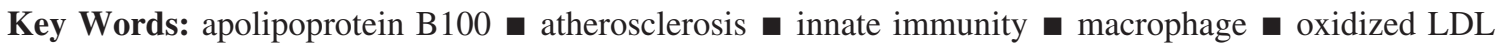

L ow-density lipoprotein (LDL) is a complex particle that comprises triglycerides and cholesteryl ester molecules in its core; unesterified cholesterol molecules, of which approximately one third lie in the core and two thirds reside on the surface; a surface monolayer of phospholipid molecules; and a single copy of apolipoprotein B100 (ApoB100) (4536 amino acids). ${ }^{1}$

\section{Clinical Perspective on p 2443}

Retention of LDL in the subendothelial space of arteries is a hallmark of the initial pathogenesis of atherosclerosis. ${ }^{2}$ Subsequently, the trapped LDL particles undergo various biochemical modifications that are mediated by oxidative, lipolytic, and proteolytic enzymes and reactive oxygen species. $^{3-5}$ Clinical and laboratory data have shown that modified LDL instigates chronic inflammatory responses in the artery wall, indicating that the modifications confer LDL with bioactivities that effect initiation, progression, and complications of atherosclerosis. ${ }^{6}$ For instance, modified phospholipids of LDL, such as lysophosphatidylcholine and 1-palmitoyl-2-(5'-oxovaleroyl)-sn-glycero-3-phosphocholine (POVPC), can stimulate endothelial cells, smooth muscle cells, and macrophages. ${ }^{7,8}$ It is known now that such atherogenic lipids initiate innate immune response through activation of Toll-like receptors..$^{9-11}$ Collectively, these data imply that modification of LDL generates endogenous ligands that

Received December 17, 2010; accepted September 22, 2011.

From the Center for Molecular Medicine, Department of Medicine, Karolinska Institute, Stockholm, Sweden (D.F.J.K., Y.W., H.L., U.H., G.K.H., Z.Y.); Departamento de Imunologia, Instituto de Ciências Biomédicas, Universidade de São Paulo, São Paulo, Brazil (F.J.O.R., M.G.); Department of Geriatrics, Qilu Hospital, Shandong University, Jinan, China (Y.W.); Department of Pharmacology, Shandong University College of Medicine, Jinan, China (H.L.); Department of Physiology, Institute of Neuroscience and Physiology, The Sahlgrenska Academy, University of Gothenburg, Gothenburg, Sweden (M.E.J.); Department of Clinical Sciences, Skåne University Hospital, Lund University, Malmö, Sweden (G.N.F., J.N.); and Department of Vascular Surgery, Karolinska University Hospital, Stockholm, Sweden (U.H.).

*Drs Ketelhuth and Rios contributed equally to this article.

The online-only Data Supplement is available with this article at http://circ.ahajournals.org/lookup/suppl/doi:10.1161/CIRCULATIONAHA.111. 051599/-/DC1.

Correspondence to Zhong-qun Yan, MD, PhD, Center for Molecular Medicine L8:03, Karolinska University Hospital, 171 76, Stockholm, Sweden. E-mail zhong-qun.yan@cmm.ki.se

(C) 2011 American Heart Association, Inc. 
trigger activation of the innate immune system that promotes atherosclerosis.

Although the hypothesis that modification of LDL plays a major role in the pathogenesis of atherosclerosis is well established, recent reports have shown that native peptides of ApoB100 trigger activation of adaptive immune responses. ${ }^{12-14}$ Using a library of malondialdehyde-modified or native polypeptides that encompassed the entire sequence of ApoB100, Fredrikson et al ${ }^{15}$ recently identified $>100$ native peptides of ApoB100 that could be recognized by circulating IgM or IgG autoantibodies from atherosclerotic patients. Subsequent work demonstrated that such native epitopes exist in carotid plaque, with nearly 3-fold higher levels in plaques from individuals with clinical symptoms than in asymptomatic individuals. ${ }^{16}$

To enhance our current understanding of the biological activities of LDL in atherosclerosis, we determined whether sequences of ApoB100 activate monocytes/macrophages. By screening a peptide library of ApoB100, we identified a peptide that had sequence-specific bioactivity, inducing inflammatory responses in innate immune cells and ex vivo cultured carotid plaques by initiating mitogen-activated protein kinase (MAPK) and $\mathrm{Ca}^{2+}$-dependent signaling pathways. We have named this novel peptide ApoB100 dangerassociated signal 1 (ApoBDS-1).

\section{Methods}

For an expanded Methods section, please refer to the online-only Data Supplement.

\section{Screen of the ApoB100 Library}

The screen for potential peptides was performed with the use of the monocytic cell line THP-1 (TIB-202; ATCC, VA). Cells were cultured in RPMI-1640 medium (Gibco Invitrogen, Carlsbad, CA) that was supplemented with $10 \%$ (vol/vol) fetal calf serum (SigmaAldrich, St Louis, MO), penicillin (100 U/mL)/streptomycin (100 $\mu \mathrm{g} / \mathrm{mL}$ ) (Sigma-Aldrich), $2 \mathrm{mmol} / \mathrm{L} \mathrm{L}$-glutamine (Gibco Invitrogen), $15 \mathrm{mmol} / \mathrm{L}$ HEPES (Gibco Invitrogen), and $11 \mathrm{mmol} / \mathrm{L}$ sodium bicarbonate (Sigma-Aldrich) and maintained in a humidified atmosphere of $5 \% \mathrm{CO}_{2}$ at $37^{\circ} \mathrm{C}$. For the experiments, $2.5 \times 10^{5}$ cells per well were incubated in duplicate with each of native ApoB100 peptides.

\section{Ex Vivo Stimulation of Atherosclerotic Plaque Tissue}

Eight carotid artery plaques were collected from patients who were undergoing endarterectomy at Karolinska University Hospital. Informed consent was obtained from all subjects. The investigation was approved by the Ethical Committee of Northern Stockholm and was in agreement with institutional guidelines and the principles that have been set forth in the Declaration of Helsinki.

Fresh plaques were processed to remove calcified tissue, cut into small pieces $\left(<2 \mathrm{~mm}^{3}\right)$, and washed with cold phosphate-buffered saline. The pieces were distributed equally in a 48 -well plate $(\approx 0.1$ mg per well). Two to 4 hours after incubation in RPMI with $10 \%$ fetal calf serum, the tissues were stimulated in duplicate for 24 hours with the indicated concentrations of ApoBDS-1.

\section{Immunofluorescent Detection of ApoBDS-1 in Carotid Atherosclerotic Plaques}

For detection of ApoBDS-1, an affinity-purified rabbit $\mathrm{IgG}$ antiApoBDS-1 antibody was generated (Anaspec, San Jose, CA). The reactivity was verified against a set of ApoB100 peptides, demonstrating high specificity to ApoBDS-1 (Figure I in the online-only Data Supplement). Immunofluorescent staining for ApoBDS-1 was performed on acetone-fixed frozen sections from 4 carotid endarterectomy plaques with the use of the ApoBDS-1 antibody, followed by DyLight 594 anti-rabbit IgG antibody (Vector Laboratories, Burlingame, CA). Sections from each plaque were costained with monoclonal antibody against human smooth muscle $\alpha$-actin (M0851; Dako, Glostrup, Denmark), monoclonal antibody against human von Willebrand factor (M0616; Dako), or monoclonal antibody against human CD68 (556059; BD Biosciences, Franklin Lakes, NJ). Images were captured with a Leica TCS SP5 confocal microscope (Leica, Wetzlar, Germany).

As a specificity control, ApoBDS-1 peptide $(20 \mu \mathrm{g} / \mathrm{mL})$ was applied to the consecutive sections stained with ApoBDS-1 antibody. The specific ApoBDS-1 signals were quantified. In brief, fluorescence per pixel was obtained by the conversion of images to grayscale and a definition of global threshold with the use of Otsu's method. ${ }^{17}$ Total number of pixels above the threshold was calculated with the use of Matlab software (MathWorks, MI).

\section{Detection of ApoBDS-1 in Carotid Plaque Homogenates}

Plaques were rinsed in cold phosphate-buffered saline and disrupted in cold T-PER tissue protein extraction reagent (Thermo Scientific, MA) supplemented with Halt protease inhibitor cocktail and EDTA (Thermo Scientific) with the use of an Ultraturrax homogenizer (IKA-Labortechnik, Germany). Crude homogenates were centrifuged at $10000 \mathrm{~g}$ for 10 minutes, and the supernatant was used for identification of ApoBDS-1. The protein content was determined by Bradford (BioRad, LA).

For Western blot analysis of ApoBDS-1, samples were diluted with Laemmli sample buffer (Bio-Rad), boiled, and loaded in equal concentrations; $0.5 \mu \mathrm{g}$ of ApoBDS-1 was included as a positive control. Samples were separated by $10 \%$ sodium dodecyl sulfate polyacrylamide gel electrophoresis and transferred to a polyvinylidene fluoride membrane (GE Healthcare, Uppsala, Sweden) with the use of a semidry electrophoretic transfer cell at $125 \mathrm{~mA}$ for 45 minutes. ApoBDS-1-containing fragments were detected with the use of the anti-ApoBDS-1 antibody (1.6 $\mu \mathrm{g} / \mathrm{mL}$ ), followed with goat anti-rabbit IgG-horseradish peroxidase (Dako), and visualized with an enhanced chemiluminescence substrate (GE Healthcare).

For the chromatographic analysis, $2 \mathrm{mg}$ of plaque homogenate was fractionated with the use of an HR10/30 Superose 6 column (GE Healthcare) and a Discovery BIO GFC-500 as precolumn (5 $\mathrm{cm} \times 7.8$ ID; Supelco, Sigma-Aldrich) coupled to a Prominence ultrafast liquid chromatography system (Shimadzu, Kyoto, Japan) and equilibrated with ammonium bicarbonate buffer, $\mathrm{pH} 7.4$. Forty-eight fractions of $500 \mu \mathrm{L}$ each were collected on a 96-well enzyme-linked immunosorbent assay plate with a Foxy Jr fraction collector (Teledyne Isco Inc, NE). Molecular weight calibration of the system was performed (Figure II in the online-only Data Supplement) with the use of high- and low-molecular-weight calibration kits (GE Healthcare). To detect ApoBDS-1, 96-well plates were coated overnight with the collected fractions, blocked with $1 \%$ gelatin for 1 hour, and then incubated with antiApoBDS-1 $(1 \mu \mathrm{g} / \mathrm{mL})$ for 2 hours at room temperature. After they were washed, the samples were incubated with horseradish peroxidase-conjugated goat anti-rabbit antibody (Dako) and developed with the use of $3,3^{\prime}, 5,5^{\prime}$-tetramethybenzidine (BD Biosciences, Franklin Lakes, NJ). The absorbance was measured with a microplate reader (VersaMax; Molecular Devices, Sunnyvale, CA).

\section{Assessment of the Activity of ApoBDS-1-Positive Fractions}

Chromatographic fractions from atherosclerotic plaque were obtained as mentioned above. The collected fractions were resuspended 
Table. Apolipoprotein B100 Peptide Sequences

\begin{tabular}{lcc}
\hline Peptide ID & $\begin{array}{c}\text { Amino Acid } \\
\text { Sequence }\end{array}$ & $\begin{array}{c}\text { Position in Apolipoprotein } \\
\text { B100 Protein Sequence }\end{array}$ \\
\hline P208 & PEMRLPYTIITTPPLKDFSL & aa $3106-3125$ \\
P211 & KKNKHRHSITNPLAVLCEFI & aa $3151-3170$ \\
P216 (ApoBDS-1) & VPVVNVEVSPFTIEMSAFGY & aa 3226-3245 \\
P218 & FSILGSDVRVPSYTLILPSL & aa 3256-3275 \\
P243 & HLDIAGSLEGHLRFLKNIIL & aa $3631-3650$ \\
P292 & IVGWTVKYYELEEKIVSLIK & aa $4366-4385$ \\
P216a & VPVVNVEVSP & aa $3226-3235$ \\
P216b & VEVSPFTIEM & aa 3232-3241 \\
P216c & FTIEMSAFGY & aa 3236-3245 \\
\hline
\end{tabular}

ApoBDS-1 indicates apolipoprotein B100 danger-associated signal 1.

in RPMI 1640 with $1 \%$ fetal calf serum and incubated with peripheral blood mononuclear cells (PBMCs) $\left(2.5 \times 10^{5}\right.$ cells per well). For blocking experiments, PBMCs were preincubated with p216c $(60 \mu \mathrm{g} / \mathrm{mL})$ for 30 minutes. Levels of interleukin (IL)-8 in supernatant were assessed after 24 hours of incubation by enzymelinked immunosorbent assay.

\section{Statistical Analysis}

Quantitative data are expressed as mean \pm SEM. The nonparametric Mann-Whitney $U$ test was used for 2-group comparisons, and the Kruskal-Wallis test was used for multigroup comparisons. Differences between groups were considered significant at $P<0.05$.

\section{Results}

\section{Identification of ApoBDS-1 in ApoB100}

To determine whether ApoB100-derived peptides have bioactivity to stimulate monocyte/macrophages, THP-1 cells were treated with 302 synthetic peptide of ApoB100. IL-8 secretion was used to reveal cell activation. At $25 \mu \mathrm{g} / \mathrm{mL}$, we observed that at least 6 native peptides-P208, P211, P218, P243, P292, and P216 (Table)-triggered IL-8 production (Figure 1A).

To confirm these initial observations, the activity of these peptides was examined in THP-1 cells. Among them, P216 was the most effective peptide, eliciting dosedependent production of IL-8 (Figure 1B), and it was termed ApoBDS-1.

During LDL oxidation, a common modification is the addition of malondialdehyde adducts to the lysyl residues of ApoB100. ${ }^{4}$ Notably, the modification of ApoBDS-1 with malondialdehyde quenched its bioactivity (Figure 1C).

In addition to THP-1 cells (Figure 1B), primary cells from blood were also examined. Human PBMCs (Figure 2A) and monocyte-derived macrophages (Figure 2B) were more sensitive to ApoBDS-1 than THP-1 cells, as evidenced by a 10 -fold increase in IL-8 production. Consistent with its effect on IL-8 production, ApoBDS-1 upregulated IL-8 mRNA levels in PBMCs (Figure 2C). Collectively, these results demonstrate that ApoBDS-1 is a distinct peptide of ApoB100 that has robust bioactivity, inducing IL-8 secretion by monocytes and macrophages.

Because lipopolysaccharide is a widespread contaminant of biochemical preparations and active at extremely low concentrations, we determined whether the effect of ApoBDS-1 was attributed to lipopolysaccharide contamination. Four independent batches of synthetic ApoBDS-1 were tested, showing consistent activity throughout this study, arguing against coincidental lipopolysaccharide contamination (data not shown). Furthermore, ApoBDS-1-induced IL-8

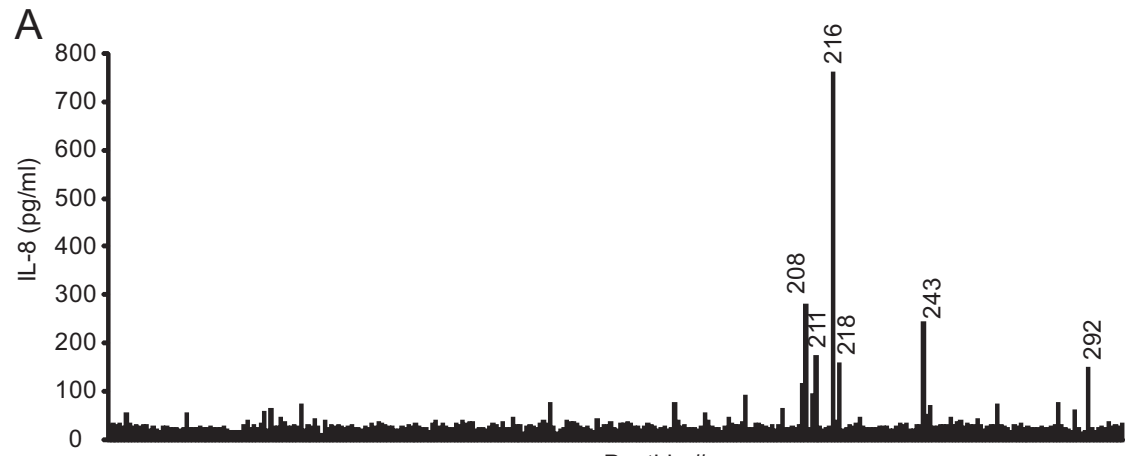

Peptide \#

B

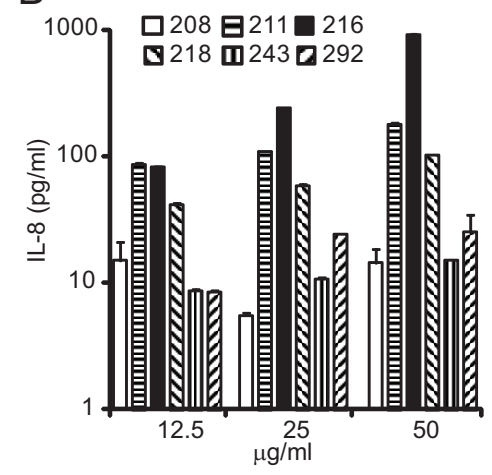

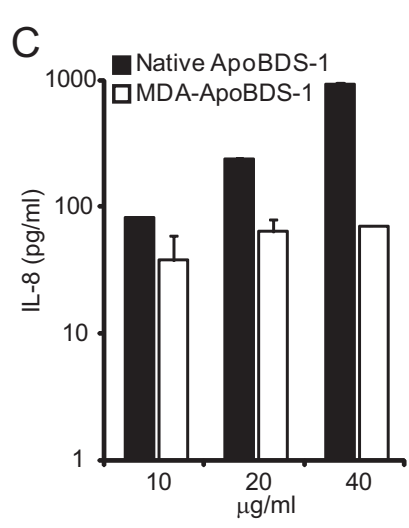

Figure 1. Identification of apolipoprotein B100 danger-associated signal 1 (ApoBDS-1). A, THP-1 cells $\left(2.5 \times 10^{5}\right)$ were incubated in duplicate with 25 $\mu \mathrm{g} / \mathrm{mL}$ of each individual apolipoprotein B100 peptide. Each bar represents the interleukin (IL)-8 released in response to the corresponding peptide. Medium alone was used as negative control. B, Potential bioactive peptides identified in $\mathbf{A}$ were reevaluated. THP- 1 cells $\left(2.5 \times 10^{5}\right)$ were incubated in duplicate with $12.5,25$, and $50 \mu \mathrm{g} / \mathrm{mL}$ of peptides P208, P211, P216, P218, P243, and P292. Data show mean \pm SEM. C, Malondialdehyde (MDA) modification of P216 (ApoBDS-1). THP-1 cells $\left(2.5 \times 10^{5}\right)$ were incubated in duplicate with 40,20 , or $10 \mu \mathrm{g} / \mathrm{mL}$ of native and malondialdehyde-modified ApoBDS-1. 


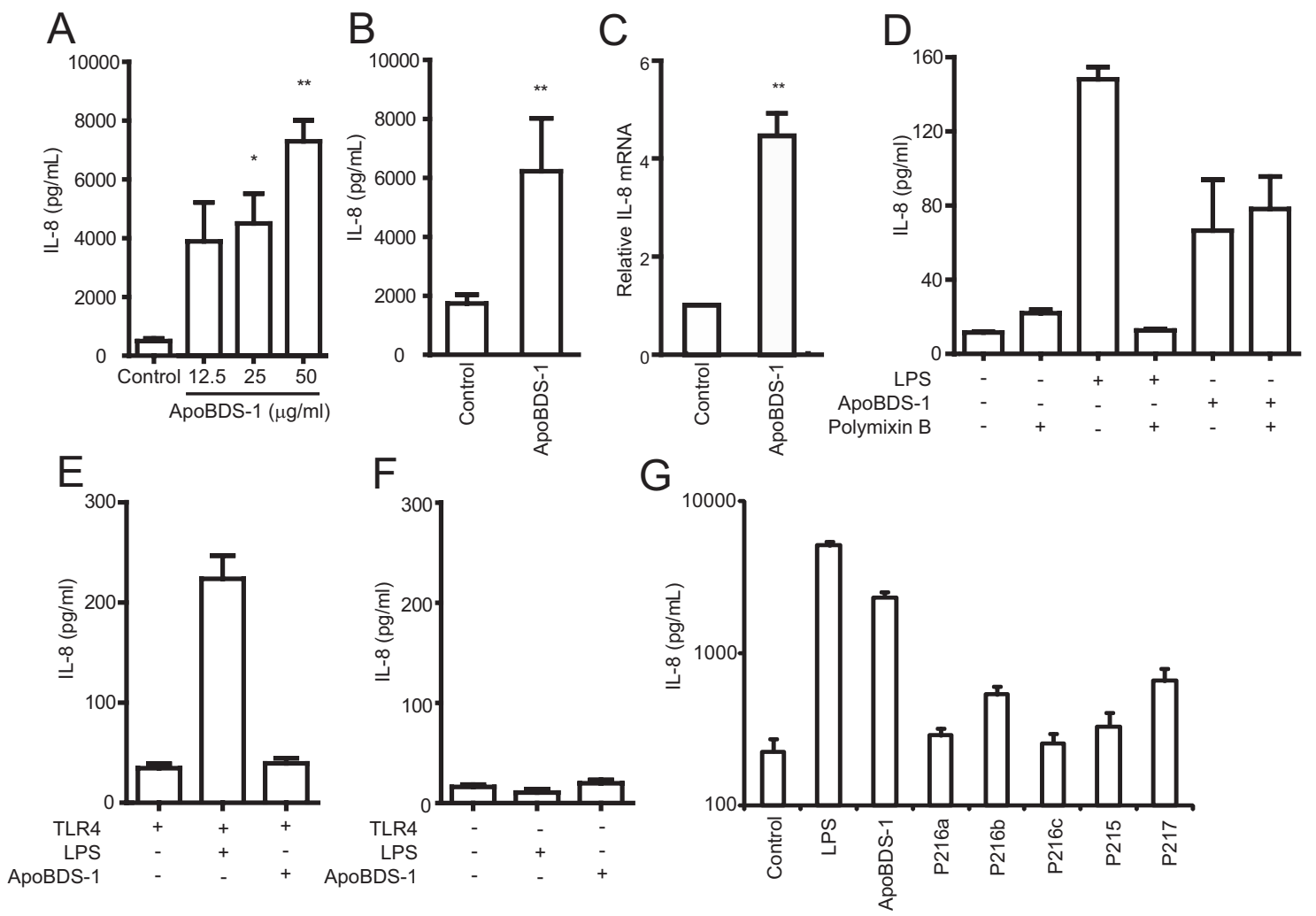

Figure 2. Apolipoprotein B100 danger-associated signal 1 (ApoBDS-1)-dependent secretion of interleukin (IL)-8 is sequence specific and independent of Toll-like receptor 4 (TLR4). Peripheral blood mononuclear cells (4 donors) (A) and monocyte-derived macrophages (4 donors) (B) were stimulated with ApoBDS-1 $(25 \mu \mathrm{g} / \mathrm{mL})$ for 24 hours. IL-8 production was measured by enzymelinked immunosorbent assay; data are mean \pm SEM. ${ }^{\star} P<0.05$, ${ }^{\star \star} P<0.01$ compared with control. C, mRNA levels of IL-8 were measured in peripheral blood mononuclear cells after 5 hours of incubation. Data are mean \pm SEM of IL-8 mRNA levels of peripheral blood mononuclear cells from 4 donors. ${ }^{*} P<0.01$ compared with control. D, THP- 1 cells $\left(2.5 \times 10^{5}\right)$ were stimulated with ApoBDS-1 $(25 \mu \mathrm{g} / \mathrm{mL})$ and lipopolysaccharide (LPS) $(100 \mathrm{ng} / \mathrm{mL})$ in the presence or absence of polymyxin B (10 $\mu \mathrm{g} / \mathrm{mL})$. IL-8 in supernatant was measured after 24 hours. Results show mean \pm SEM and are representative of 2 independent experiments. Human embryonic kidney-293/TLR4 (E) or human embryonic kidney-293 (F) cells, respectively, were stimulated with lipopolysaccharide $(100 \mathrm{ng} / \mathrm{mL})$ or ApoBDS-1 $(25 \mu \mathrm{g} / \mathrm{mL})$. IL-8 in the supernatant was measured after 24 hours. Data are mean \pm SEM of 4 independent experiments. G, Peripheral blood mononuclear cells $\left(2.5 \times 10^{5}\right)$ were incubated with ApoBDS $-1(25 \mu \mathrm{g} / \mathrm{mL})$ or the same concentration of truncated ApoBDS-1 (P216a, P216b, and P216c), P215, P217, or lipopolysaccharide (100 ng/mL). Supernatant IL-8 was measured after 24 hours. Data are mean \pm SEM of 4 donors.

production was unaffected by the lipopolysaccharide inhibitor polymyxin B, which suppressed $>90 \%$ of lipopolysaccharide-induced IL-8 levels (Figure 2D). In addition, IL-8 could not be induced by ApoBDS-1 in human embryonic kidney cells that were stably transfected with Toll-like receptor 4 (Figure 2E). These data demonstrate that activation by ApoBDS-1 is not caused by lipopolysaccharide contamination.

\section{The Bioactivity of ApoBDS-1 Is Sequence Dependent}

To gain insights into its sequence-activity relationship, ApoBDS-1 was truncated into 3 short fragments, each consisting of 10 amino acids (Table). None of the truncated fragments induced IL-8 production in PBMCs (Figure 2G). Furthermore, P215 and P217, the peptides flanking on either end of ApoBDS-1 in the sequence of ApoB100, were used as controls and failed to elicit IL-8 secretion (Figure 2G).

\section{Effect of ApoBDS-1 on Induction of Proinflammatory Mediators}

To examine the function of ApoBDS-1 in the proinflammatory response in greater detail, 10 additional chemokines and cytokines were measured by cytometric bead array in the supernatants of PBMCs that were incubated with ApoBDS-1 for 6 and 24 hours (Figure 3). IL-6 (Figure 3A) was rapidly induced by ApoBDS-1 at 6 hours, followed by IL-8 and CCL2 (monocyte chemotactic protein-1) production at 24 hours (Figure 3B). There was no effect, however, on IL-1 $\beta$, tumor necrosis factor- $\alpha$, IL-12p70, interferon- $\gamma$, IL-10, CXCL10 (IP-10), or CXCL9 (MIG) (Figure 3). These data suggest that ApoBDS-1 influences a subset of inflammatory mediators, including an unexpected downregulation of CCL5 release after 24 hours of treatment (Figure 3B).

\section{ApoBDS-1 Increases Calcium Flux and MAPK Phosphorylation}

Next we explored the signaling mechanisms implicated in the ApoBDS-1-induced cytokine and chemokine responses. Cal- 


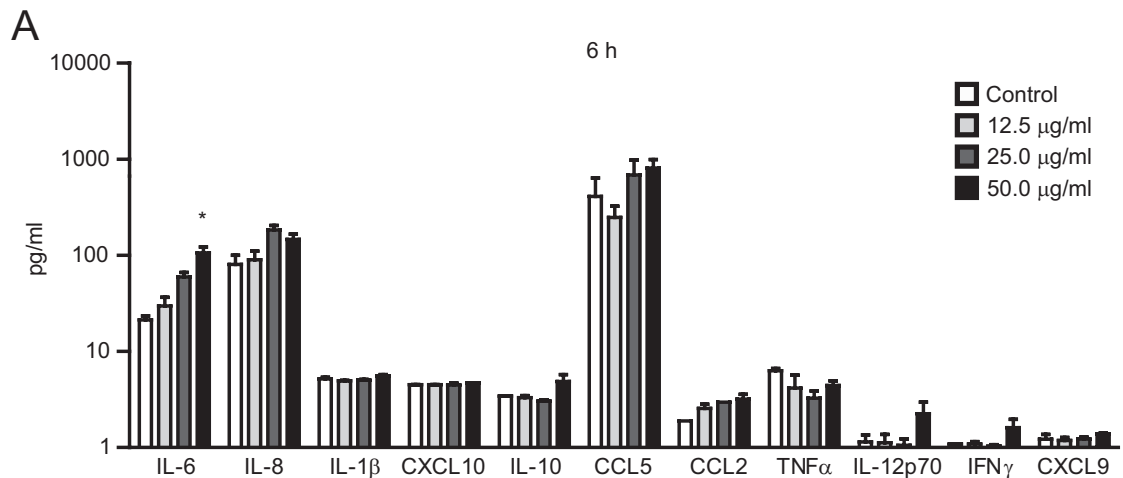

Figure 3. Apolipoprotein B100 dangerassociated signal 1-induced soluble mediators. Peripheral blood mononuclear cells $\left(2.5 \times 10^{5}\right)$ were incubated with 3 concentrations of apolipoprotein B100 dangerassociated signal 1 for 6 hours (A) or 24 hours (B). Supernatant interleukin (IL)-6,

B IL-8, IL-1 $\beta$, CXCL10, IL-10, CCL5, CCL2,

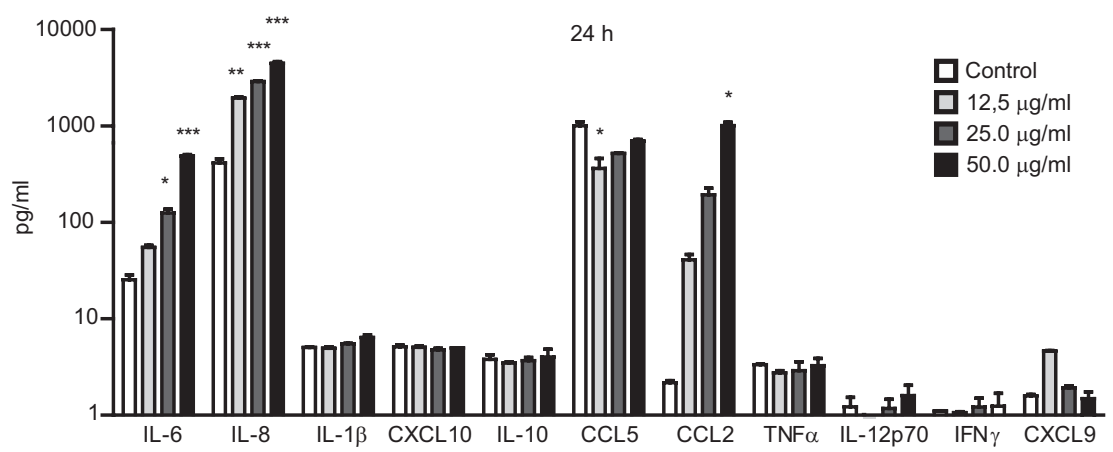
tumor necrosis factor (TNF)- $\alpha$, IL-12p70, interferon (IFN)- $\gamma$, and CXCL9 were measured by cytometric bead array. Data are mean \pm SEM. ${ }^{*} P<0.05,{ }^{* \star} P<0.01$, ${ }^{\star \star *} P<0.001$ compared with control.

cium signaling is critical for the activation of transcriptional regulatory pathways that underlie inflammatory and immune responses. ${ }^{18}$

We observed that PBMCs responded to ApoBDS-1 by a rapid increase in $\mathrm{Ca}^{2+}$ flux within 30 seconds (Figure 4A and 4B) and subsequent slow decline over 240 seconds, with leveling off (Figure 4B). Importantly, ApoBDS-1-induced IL-8 production was completely abolished in the presence of the calcium chelator 1,2-bis(2-aminophenoxy) ethane$\mathrm{N}, \mathrm{N}, \mathrm{N}^{\prime}, \mathrm{N}^{\prime}$-tetraacetic acid (BAPTA) (Figure 4C), indicating that $\mathrm{Ca}^{2+}$ flux is an early but also a critical signaling mechanism in the course of ApoBDS-1-triggered IL-8 production.

Because $\mathrm{Ca}^{2+}$ signaling is implicated in the modulation of MAPK pathways, we examined the response of MAPKs in THP-1 cells treated with ApoBDS-1. Activated ERK1/2 and JNK were evident 10 minutes and 60 minutes after ApoBDS-1 stimulation (Figure 4D). p38, however, responded in a distinct manner characterized by gradually activating over time and peaking at 60 minutes (Figure 4D).

Next MAPK inhibitors were used to determine the role of MAPKs in ApoBDS-1-induced IL-8 production. Pretreatment of PBMCs with the ERK1/2 specific inhibitor PD98089 or the JNK specific inhibitor SP600125 did not affect ApoBDS-1-induced IL-8 mRNA expression or IL-8 release (Figure 4E and 4F). In contrast, blockade of p38 with SB203580 resulted in $>90 \%$ reduction of IL- 8 mRNA and protein (Figure 4E and 4F). These data show that p38-MAPK is the critical signaling mechanism underlying ApoBDS-1induced IL- 8 production.

\section{ApoBDS-1 Elicits Inflammatory Responses in Atherosclerotic Lesions}

To determine the relevance of ApoBDS-1 to inflammation in atherosclerosis, we established an ex vivo atherosclerotic model using fresh atherosclerotic plaque tissue from human carotid arteries. Eight plaques were stimulated with 2 concentrations of ApoBDS-1, and levels of inflammatory mediators were measured 24 hours later.

The ex vivo cultured plaques released high levels of IL-8, IL-6, and CCL5 in an unstimulated condition (Figure 5A). Notably, ApoBDS-1 increased the production of IL-8 and IL-6 but not CCL5 (Figure 5A), consistent with the responses of in vitro treated PBMCs (Figure 3).

Furthermore, ApoBDS-1 triggered a dose-dependent production of the proinflammatory prostaglandin $\mathrm{E}_{2}$ (PGE2) (Figure 5A), concomitant with a significant upregulation of microsomal prostaglandin $\mathrm{E}_{2}$ synthase (mPGES-1) mRNA (Figure 5B) and IL-8 in plaques (Figure 5B). However, expressions of cyclooxygenase-1, cyclooxygenase-2, or the PGE2 receptors EP2, EP3, or EP4 were not greatly altered (Figure 5B).

\section{ApoBDS-1-Positive Peptides Are Present in Carotid Atherosclerotic Plaques}

To further establish the relevance of ApoBDS-1 to atherosclerosis, we verified whether ApoBDS-1 exists in atherosclerotic lesions. For this purpose, we made an antibody that shows definitive specificity to ApoBDS-1 (Figure I in the online-only Data Supplement) and analyzed ApoBDS-1 in vivo by immunostaining. As shown in Figure 6A, abundant ApoBDS-1 signals were observed in extracellular and intracellular spaces in atherosclerotic specimens of human carotid 

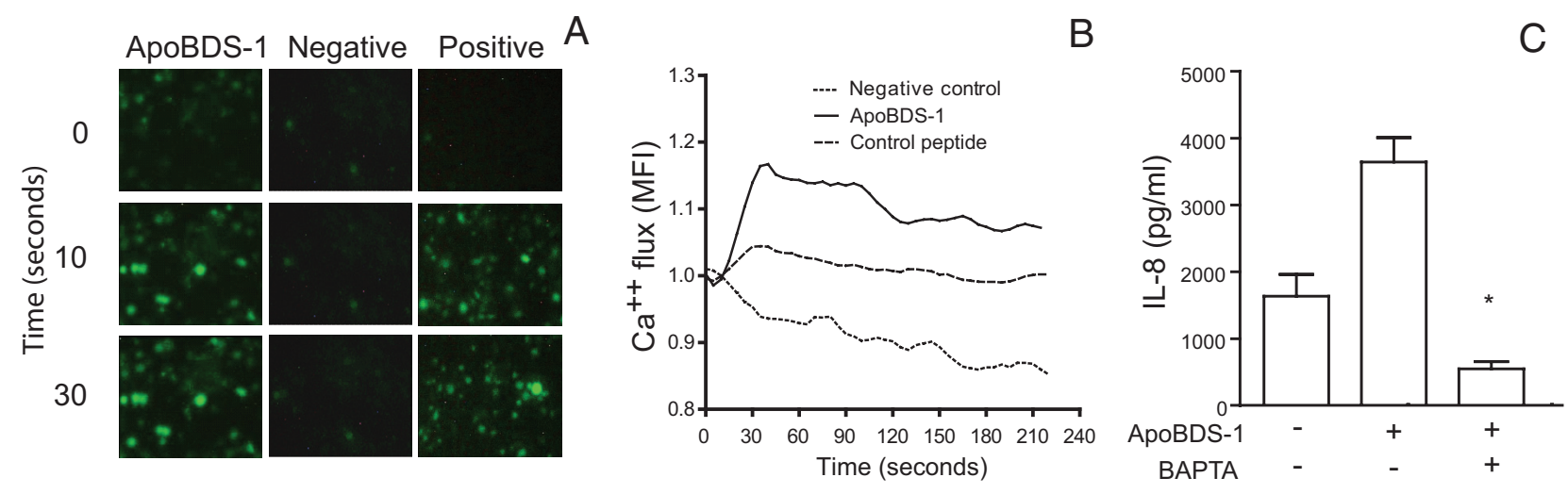

D

$E$
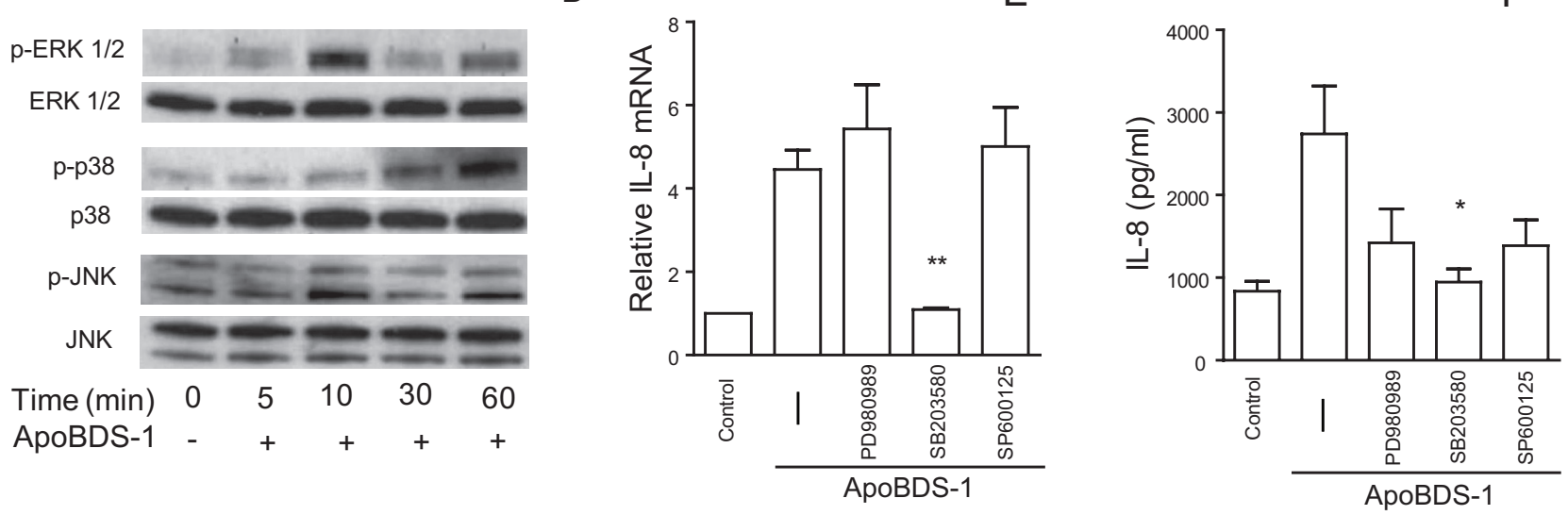

Figure 4. Apolipoprotein B100 danger-associated signal 1 (ApoBDS-1) induces calcium flux and mitogen-activated protein kinase phosphorylation. A and B, Peripheral blood mononuclear cells $\left(1 \times 10^{6}\right)$ were stimulated with ApoBDS-1 (25 $\left.\mu \mathrm{g} / \mathrm{mL}\right)$ or positive control calcium ionophore $(2.5 \mu \mathrm{mol} / \mathrm{L})$ in the presence of calcium dye (Fluo-4 AM). Increased calcium flux was recorded within 240 seconds by fluorescence microscopy (A) and a fluorescence reader (B). Medium alone and P265 (25 $\mu \mathrm{g} / \mathrm{mL})$, an inactive peptide, were used as negative controls. Results are representative of 3 independent experiments. C, Peripheral blood mononuclear cells $\left(2.5 \times 10^{5}\right)$ were incubated with ApoBDS-1 (25 $\mu \mathrm{g} / \mathrm{mL})$ with or without the calcium chelator 1,2-bis(2-aminophenoxy) ethane-N,N,N',N'-tetraacetic acid (BAPTA). Interleukin (IL)-8 was measured after 24 hours. Data are mean \pm SEM of 4 donors. ${ }^{\star} P<0.05$ compared with cells treated with ApoBDS-1 alone. D, Western blot analysis of ERK1/2, p38, and JNK activation in THP-1 cells stimulated with ApoBDS-1 (25 $\mu \mathrm{g} / \mathrm{mL}$ ). Results are representative of 4 independent experiments. $\mathbf{E}$ and $\mathbf{F}$, The effect of mitogen-activated protein kinase inhibitors on the regulation of IL-8 in peripheral blood mononuclear cells. Peripheral blood mononuclear cells $\left(2.5 \times 10^{5}\right)$ were incubated with ApoBDS- 1 (25 $\mu \mathrm{g} / \mathrm{mL}$ ) in the presence or absence of PD98059 (ERK1/2 inhibitor), SB203580 (p38 inhibitor), and SP600125 (JNK inhibitor). After 5 and 24 hours, IL-8 was measured by real-time polymerase chain raction (E) and by enzyme immunosorbent assay (F), respectively. Results are presented as mean \pm SEM of 5 donors. ${ }^{\star} P<0.05$, ${ }^{\star \star} P<0.01$ compared with cells treated with ApoBDS- 1 .

artery. The specificity of the observed ApoBDS-1 signals was confirmed by competitive blocking with the use of ApoBDS-1 peptide (Figure 6B and 6C). Of note, the intracellular ApoBDS-1 signal was predominantly colocalized with CD68 positive macrophages (Figure 6D), occasionally with smooth muscle cells (Figure 6E), but was not found in endothelial cells (Figure 6F). These results show that ApoBDS-1-containing peptides are present in atherosclerotic lesions.

\section{Evidence of Low-Molecular-Weight ApoBDS-1-Positive Peptides in Atherosclerotic Plaques}

To further characterize the endogenous ApoBDS-1 peptides, plaque homogenates were analyzed. Western blot analysis of denatured plaque proteins showed that ApoBDS-1 peptides are present in different molecular weights in vivo (Figure 7A). Two small ApoBDS-1 peptide fragments (ie, $\approx 40$ and $15 \mathrm{kDa}$ in molecular weight) were noted in all tested plaques.
Separation of plaque homogenates in nonreducing condition by size-exclusion chromatography followed by detection of ApoBDS-1 with the use of the anti-ApoBDS-1 antibody confirmed that a major portion of ApoBDS-1 peptides exists in vivo in molecular weights ranging between 10 and $42 \mathrm{kDa}$ (Figure 7B).

\section{Low-Molecular-Weight Endogenous ApoBDS-1-Positive Fractions Contain ApoBDS-1-Specific Capacity to Trigger \\ IL-8 Production}

Finally, we investigated whether the peptides isolated from plaque carry the bioactivity of ApoBDS-1. PBMCs were incubated with 7 ApoBDS-1-positive chromatographic fractions corresponding to the calibrated molecular weight 10 to $42 \mathrm{kDa}$. In accordance, all 7 fractions significantly enhanced IL-8 production (Figure III in the online-only Data Supplement). 

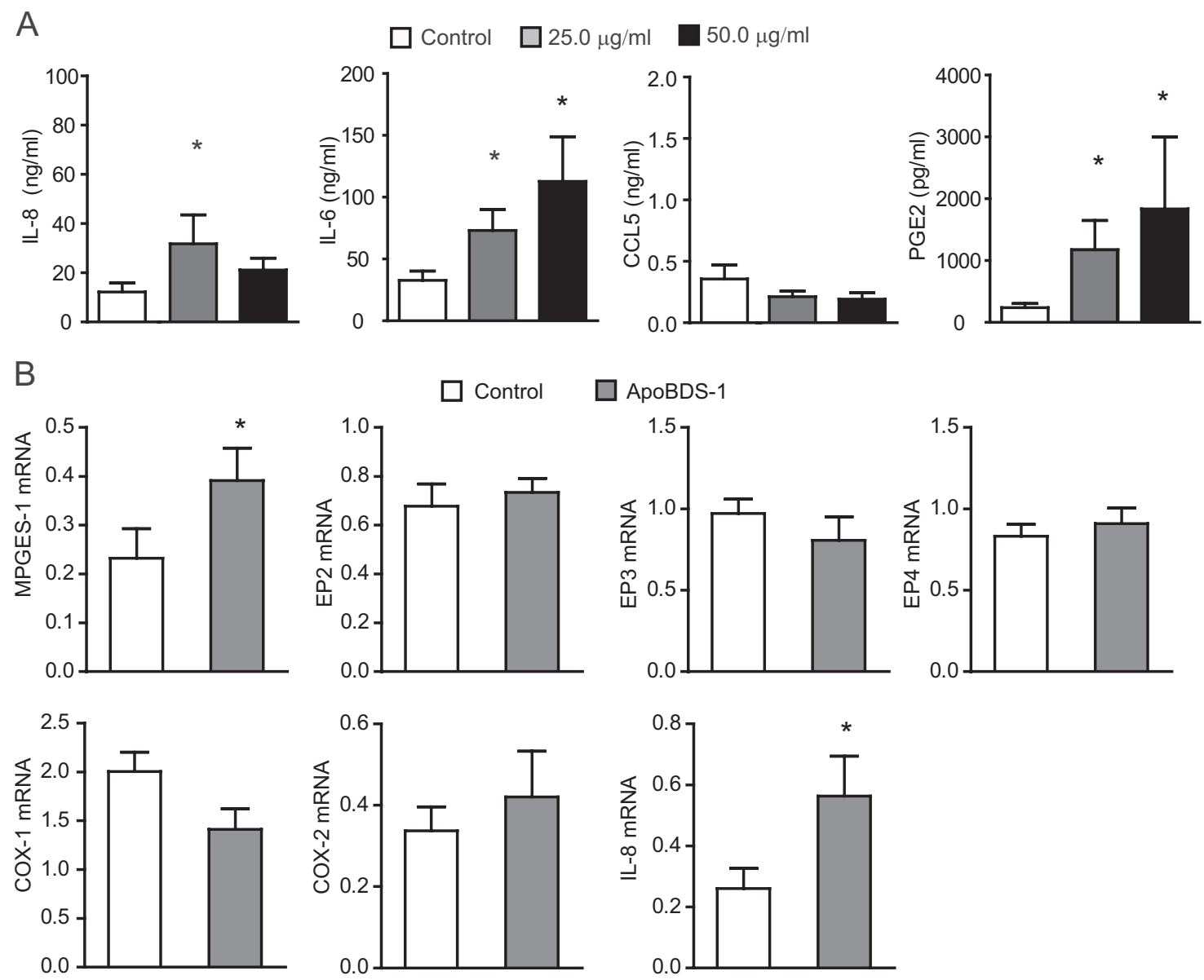

Figure 5. Apolipoprotein B100 danger-associated signal 1 (ApoBDS-1) induces inflammatory responses in the supernatant of ex vivo cultures of atherosclerotic plaques. Fresh atherosclerotic carotid plaques were cut into small pieces and distributed equally in a 48-well plate $(\approx 0.1 \mathrm{mg} / \mathrm{mL}$, wt/vol). A, Cultures were stimulated with 25 or $50 \mu \mathrm{g} / \mathrm{mL}$ of ApoBDS-1 in duplicate for 24 hours. Interleukin (IL)-8, IL-6, CCL5, and prostaglandin $E_{2}$ (PGE2) in supernatant were measured by enzyme-linked immunosorbent assay. ${ }^{*} P<0.05$ compared with control. B, Cultures were stimulated with $25 \mu \mathrm{g} / \mathrm{mL}$ of ApoBDS-1 in duplicate for 24 hours. mRNA levels of microsomal prostaglandin $\mathrm{E}_{2}$ synthase (mPGES-1), EP2, EP3, EP4, cyclooxygenase (COX)-1, COX-2, and IL-8 in the plaque tissue were measured by real-time polymerase chain reaction 24 hours after ApoBDS- 1 stimulation. Data are mean \pm SEM of 8 plaque samples. ${ }^{*} P<0.05$ compared with control.

To define the specific ApoBDS-1 activity in these peptide fractions, the response of IL- 8 was determined in the presence of excess peptide P216c, a truncated ApoBDS-1 that lacks biological activity (Figure $2 \mathrm{G}$ and Figure IV in the online-only Data Supplement). All 7 fractions were partially blocked to various degrees by P216c; 1 fraction collected at 49 minutes was overtly affected, as indicated by a $63 \%$ reduction in IL- 8 response in the presence of $\mathrm{p} 216 \mathrm{c}$ (Figure 7C). Altogether, these results imply that peptides with ApoBDS- 1 activity can be found in atherosclerotic plaque.

\section{Discussion}

Inflammatory properties of modified LDL contribute to the development of atherosclerosis. ${ }^{19-21}$ In this study, we investigated the relevance of peptides derived from the protein part of LDL, ApoB100, to the inflammatory response in atherosclerosis.

By screening a peptide library of human ApoB100, we have identified a previously unrecognized native peptide fragment that exhibits distinctive activity triggering inflammatory responses in human monocytes/macrophages and atherosclerotic plaques ex vivo. Importantly, the peptides with specific ApoBDS-1 activity are present in atherosclerosis. Given its capacity to induce innate immune responses, we named the peptide ApoBDS-1, signifying the first identified ApoB100-derived danger-associated signal.

ApoBDS-1 has several important properties that contribute to inflammation in atherosclerosis. The molecular mechanism that evokes infiltration of leukocytes into the arterial wall is crucial for the development of atherosclerosis. Our results indicate that ApoBDS-1 induces the production of a subset of chemokines that are implicated in the recruitment of monocytes and $\mathrm{T}$ lymphocytes in chronic inflammatory diseases, including atherosclerosis. Furthermore, ApoBDS-1 is a potent stimulus of mPGES-1 pathway, resulting in augmentation of PGE2 biosynthesis in the atherosclerotic lesion. Because PGE2 can aggravate the inflammatory response and evoke progression of atherosclerosis at least in part by enhancement of vascular oxidative stress, by impairing endothelial function, and by modulation of platelet aggregation 

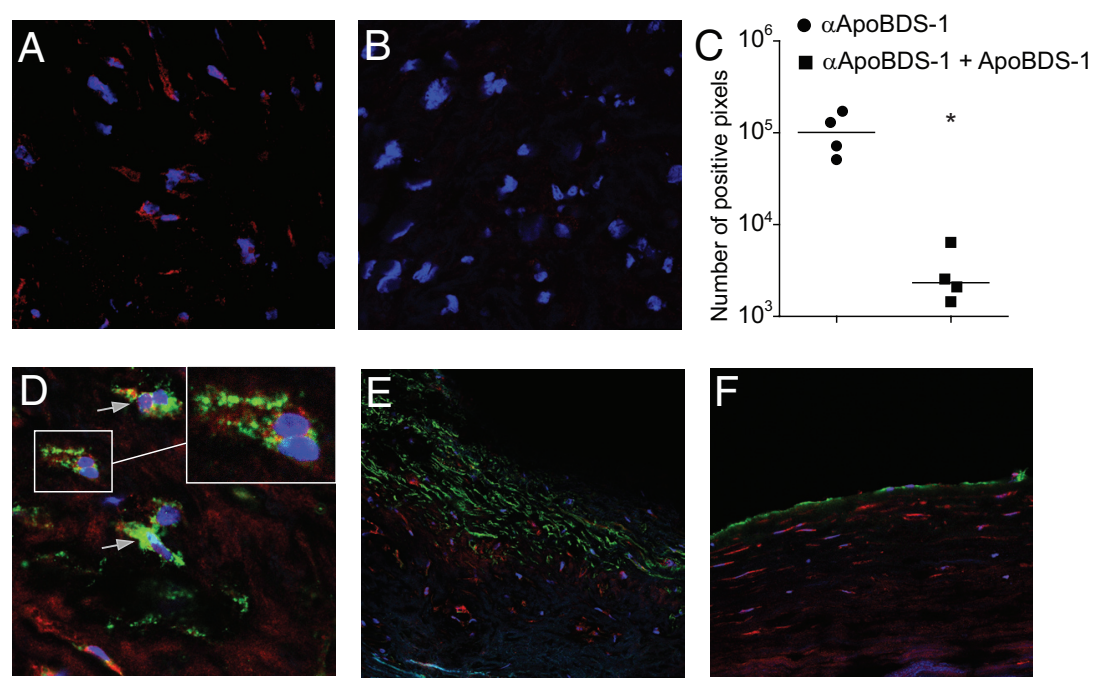

Figure 6. Immunofluorescent detection of apolipoprotein B100 danger-associated signal 1 (ApoBDS-1) in human carotid plaques. Frozen sections of human carotid plaques were fixed with acetone and stained with anti-ApoBDS-1 antibody (red) (A) or anti-ApoBDS-1 in combination with ApoBDS-1 peptide (B) for specificity control; ${ }^{*} P<0.05$ for results of plaques stained with anti-ApoBDS-1 vs plaques stained with anti-ApoBDS-1 in combination with ApoBDS-1 peptide. C, The intensity of ApoBDS-1 staining in 4 different carotid plaques was quantified and compared in the presence or absence of ApoBDS-1. Double immunostaining was used for colocalization of ApoBDS-1 (red) with CD68-positive macrophages (green) (D), smooth muscle cell $\alpha$-actin (green) (E), and von Willebrand factor (green) (F). Nuclei were visualized with DAPI (blue). In D, inset details ApoBDS-1 colocalization with CD68. Images were acquired at $\times 400$ magnification with confocal microscopy.

and arterial thrombosis, ${ }^{22-25}$ it is likely that ApoBDS-1 has an important impact on the pathogenic processes of atherosclerosis. In support of this concept, we have shown that ApoBDS-1 also induces IL-6, another pleiotropic cytokine with detrimental effects on atherosclerotic plaque development. ${ }^{26,27}$ These bioactivities, as demonstrated in our ex vivo model of atherosclerosis, link ApoBDS-1 to its pathogenesis.

Whereas ApoBDS-1 induces production of IL-6, IL-8, and PGE2, it does not trigger expression of potent proinflammatory cytokines, such as IL- $1 \beta$ and tumor necrosis factor- $\alpha$. This points to a role of ApoBDS-1 in a scenario of low-grade chronic inflammation. Of note, the in vitro cellular responses suggest that ApoBDS-1 directly activates monocytes and macrophages but not $\mathrm{T}$ lymphocytes. The molecular mechanism responsible for the cellular specificity, however, needs further investigation.

These observations postulate a new paradigm for the role of LDL in atherosclerosis. ApoBDS-1, once it is exposed or released from ApoB100 of LDL, may act alone or in concert with oxidized phospholipids as primary danger molecules, generating signals that recruit inflammatory cells into the vessel wall and precipitate chronic inflammation in the atherosclerotic lesion.

The present study has also shed light on signaling pathways involved in the peptide-induced activated inflammatory responses. Our data suggest that there are 2 related signaling modes that cooperate during ApoBDS-1-induced activation of monocytes/macrophages. Initially, rapid intracellular $\mathrm{Ca}^{2+}$ mobilization occurs on peptide stimulation and appears to be indispensable for the induction of IL-8. Subsequently, the peptide activates MAPKs, including ERK, JNK, and p38. Of the MAPKs, p38-MAPK acts as the principal signaling mechanism of the induced IL- 8 expression, based on the effects of the selective p38 inhibitor. Moreover, ERK1/2 activation seems to be involved in the regulation of IL-8 secretion. These findings suggest that 2 signaling pathways, involving $\mathrm{Ca}^{2+}$ and MAPK, coordinate to regulate IL-8 production in monocytes/macrophages.

Activation of the p38-MAPK pathway by ApoBDS-1 implicates rather broad bioactivities for this peptide in atherosclerosis. p38-MAPK has been shown to induce the inflammatory mediators tumor necrosis factor- $\alpha$, PGE2, and IL-6 and also to regulate many cellular processes, including proliferation, apoptosis, and migration. ${ }^{22,28}$ This notion is further supported by the increased response of IL-6, IL-8, and microsomal prostaglandin $\mathrm{E}_{2}$ synthase-1/ PGE2 in plaques to the peptide stimulation. Because p38-MAPK is known as the canonical signaling pathway mediating inflammatory responses induced by oxidized LDL and oxidized phospholipids, ${ }^{29,30}$ these studies together with the present study lead to the perception that activation of p38-MAPK is likely the central signaling mechanism responsible for bioactivities of LDL in atherosclerosis. The exact transmembrane signaling pathways through which ApoBDS-1 activates $\mathrm{Ca}^{2+}$ and MAPKs are unknown, and whether there is a specific receptor that interacts with ApoBDS-1 needs to be determined.

Several lines of evidence demonstrate the involvement of ApoB100-derived peptides in atherosclerosis. Clinical studies have identified antibodies that recognize modified as well as native ApoB100 peptides in association with disease progression. In fact, some of these peptides effected immune protection in experimental models of atherosclerosis. ${ }^{31-33}$ These findings show that the ApoB100 peptide library can be used to recapitulate immune responses in atherosclerosis.

Three lines of evidence in this study support the concept that bioactive ApoBDS-1 is present in atherosclerosis. Im- 

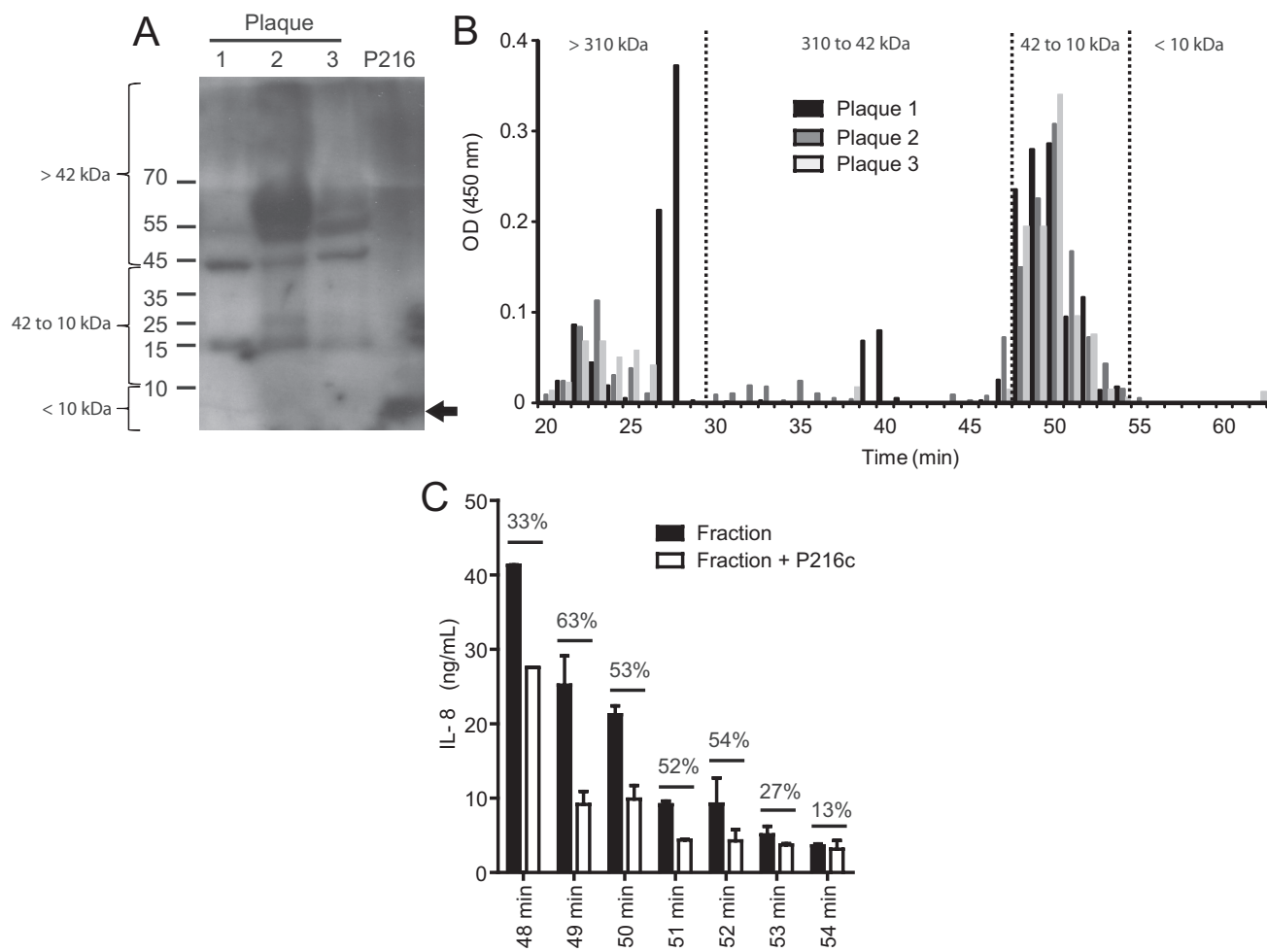

Figure 7. Detection of bioactive apolipoprotein B100 danger-associated signal 1 (ApoBDS-1) peptides generated in vivo. In vivo generated ApoBDS-1 peptides were identified by Western blot (A) or enzyme-linked immunosorbent assay of the chromatographic fractions (B) from plaque homogenates as described in Methods ( $n=3$ different plaques). Left braces indicate the different ranges of molecular weight; black arrow points to control ApoBDS-1 band; dotted lines show the different ranges of molecular weight. C, Interleukin (IL)-8 production in response to ApoBDS-1-positive chromatographic fractions with low molecular weight ranging from 10 to $42 \mathrm{kDa}$ was determined as described in Methods. Peripheral blood mononuclear cells $\left(2 \times 10^{5}\right)$ were stimulated with the peptide fractions of plaques in the presence or absence of the competitive inhibitor peptide P216c (5-fold molar ratio). IL-8 was measured after 24 hours. Data are mean \pm SEM of duplicate cultures of 1 representative experiment. Percent inhibition by P216c coincubation is presented for each fraction.

munostaining with the use of a specific antibody shows that abundant ApoBDS-1-positive signals are present in human carotid plaques. Western blot and size-exclusion chromatography analysis of plaque homogenates consistently demonstrate that ApoBDS-1-containing fragments exist in large- and also in small-molecular-weight fractions in atherosclerotic plaques. Most importantly, some of these small ApoBDS-1-positive peptide fractions carry specific ApoBDS-1 activity (ie, the capacity to induce IL-8 secretion by PBMCs). However, further studies are still needed to elucidate the sequences and the structures of these bioactive ApoBDS-1 fractions.

The process of generation of ApoBDS-1 in vivo is still poorly understood. According to the structural analysis of ApoB100 protein, ${ }^{34}$ ApoBDS-1 is in part embedded in the surface-exposed proline-rich domain 2 of ApoB100 and should therefore be susceptible to proteolytic cleavage. Indeed, trypsinization of ApoB100 results in 4 peptides from the proline-rich domain 2, 1 of which is nearly identical in sequence to ApoBDS-1. ${ }^{35}$ Protease activity in atherosclerotic lesions is high, and abundant lysosomal proteases exist in the macrophage-rich regions. ${ }^{36-38}$ Not surprisingly, in atherosclerotic lesions, ApoB100 can be processed by proteases and reactive oxygen species into various-sized peptide fragments in plaques, arguing for the fragmentation of ApoB100 as an inevitable process. ${ }^{39,40}$ We observed that abundant
ApoBDS-1 staining is colocalized with lesional macrophages or in the extracellular space in atherosclerotic lesions. However, whether the featured localization of ApoBDS-1 is implicated in the process of ApoB100 degradation and generation of the bioactive peptides needs to be clarified.

In conclusion, our study has identified a novel native ApoB100-derived peptide that activates monocytes/macrophages to secrete cytokines and chemokines. These findings shed light on the function of LDL as danger signal ${ }^{40}$ in atherosclerosis.

\section{Acknowledgments}

We thank Anneli Olsson, Ingrid Törnberg, and Linda Haglund for technical assistance.

\section{Sources of Funding}

This study was supported by the Center of Excellence for Research on Inflammation and Cardiovascular Disease Linnaeus Program, Swedish Research Council-Medicine, Swedish Heart-Lung Foundation, Swedish Foundation for Strategic Research, Vinnova Foundation, Leducq Foundation, and European Union projects (Molecular Basis of Vascular Events Leading to Thrombotic Stroke [Molstroke], Translating Innate Immune Receptor Function Into Diagnostic and Therapeutic Applications for Atherosclerosis [Immunath], and European Collaborative Project on Inflammation and Vascular Wall Remodeling in Atherosclerosis [AtheroRemo]). Drs Wang and Liu are supported by the China Scholarship Council. 


\section{Disclosures}

None.

\section{References}

1. Hevonoja T, Pentikainen MO, Hyvonen MT, Kovanen PT, Ala-Korpela M. Structure of low density lipoprotein (LDL) particles: basis for understanding molecular changes in modified LDL. Biochim Biophys Acta. 2000;1488:189-210.

2. Tabas I, Williams KJ, Boren J. Subendothelial lipoprotein retention as the initiating process in atherosclerosis: update and therapeutic implications. Circulation. 2007;116:1832-1844.

3. Oorni K, Kovanen PT. Lipoprotein modification by secretory phospholipase A(2) enzymes contributes to the initiation and progression of atherosclerosis. Curr Opin Lipidol. 2009;20:421-427.

4. Esterbauer H, Gebicki J, Puhl H, Jurgens G. The role of lipid peroxidation and antioxidants in oxidative modification of LDL. Free Radic Biol Med. 1992;13:341-390.

5. Chen K, Thomas SR, Keaney JF Jr. Beyond LDL oxidation: ROS in vascular signal transduction. Free Radic Biol Med. 2003;35:117-132.

6. Libby P, Ridker PM, Hansson GK. Inflammation in atherosclerosis: from pathophysiology to practice. J Am Coll Cardiol. 2009;54:2129-2138.

7. Watson AD, Leitinger N, Navab M, Faull KF, Horkko S, Witztum JL, Palinski W, Schwenke D, Salomon RG, Sha W, Subbanagounder G, Fogelman AM, Berliner JA. Structural identification by mass spectrometry of oxidized phospholipids in minimally oxidized low density lipoprotein that induce monocyte/endothelial interactions and evidence for their presence in vivo. J Biol Chem. 1997;272:13597-13607.

8. Gharavi NM, Alva JA, Mouillesseaux KP, Lai C, Yeh M, Yeung W, Johnson J, Szeto WL, Hong L, Fishbein M, Wei L, Pfeffer LM, Berliner JA. Role of the Jak/STAT pathway in the regulation of interleukin-8 transcription by oxidized phospholipids in vitro and in atherosclerosis in vivo. J Biol Chem. 2007;282:31460-31468.

9. Seimon TA, Nadolski MJ, Liao X, Magallon J, Nguyen M, Feric NT, Koschinsky ML, Harkewicz R, Witztum JL, Tsimikas S, Golenbock D, Moore KJ, Tabas I. Atherogenic lipids and lipoproteins trigger CD36TLR2-dependent apoptosis in macrophages undergoing endoplasmic reticulum stress. Cell Metabol. 2010;12:467-482.

10. Miller YI, Viriyakosol S, Worrall DS, Boullier A, Butler S, Witztum JL. Toll-like receptor 4-dependent and -independent cytokine secretion induced by minimally oxidized low-density lipoprotein in macrophages. Arterioscler Thromb Vasc Biol. 2005;25:1213-1219.

11. Stewart CR, Stuart LM, Wilkinson K, van Gils JM, Deng J, Halle A, Rayner KJ, Boyer L, Zhong R, Frazier WA, Lacy-Hulbert A, El Khoury J, Golenbock DT, Moore KJ. CD36 ligands promote sterile inflammation through assembly of a Toll-like receptor 4 and 6 heterodimer. Nat Immunol. 2010;11:155-161.

12. Hermansson A, Ketelhuth DF, Strodthoff D, Wurm M, Hansson EM, Nicoletti A, Paulsson-Berne G, Hansson GK. Inhibition of T cell response to native low-density lipoprotein reduces atherosclerosis. J Exp Med. 2010;207:1081-1093.

13. Ketelhuth DF, Tonini GC, Carvalho MD, Ramos RF, Boschcov P, Gidlund M. Autoantibody response to chromatographic fractions from oxidized LDL in unstable angina patients and healthy controls. Scand J Immunol. 2008;68:456-462.

14. Svensjo E, Boschcov P, Ketelhuth DF, Jancar S, Gidlund M. Increased microvascular permeability in the hamster cheek pouch induced by oxidized low density lipoprotein (oxLDL) and some fragmented apolipoprotein B proteins. Inflamm Res. 2003;52:215-220.

15. Fredrikson GN, Hedblad B, Berglund G, Alm R, Ares M, Cercek B, Chyu KY, Shah PK, Nilsson J. Identification of immune responses against aldehyde-modified peptide sequences in apoB associated with cardiovascular disease. Arterioscler Thromb Vasc Biol. 2003;23:872-878.

16. Goncalves I, Nitulescu M, Ares MP, Fredrikson GN, Jansson B, Li ZC, Nilsson J. Identification of the target for therapeutic recombinant antiapoB-100 peptide antibodies in human atherosclerotic lesions. Atherosclerosis. 2009;205:96-100.

17. Otsu N. A threshold selection method from gray-level histograms. IEEE Trans Syst Man Cybern. 1979;9:62-66.

18. Rozengurt E. Mitogenic signaling pathways induced by G proteincoupled receptors. J Cell Physiol. 2007;213:589-602.

19. Quinn MT, Parthasarathy S, Fong LG, Steinberg D. Oxidatively modified low density lipoproteins: a potential role in recruitment and retention of monocyte/macrophages during atherogenesis. Proc Natl Acad Sci U S A. 1987;84:2995-2998.

20. Quinn MT, Parthasarathy S, Steinberg D. Lysophosphatidylcholine: a chemotactic factor for human monocytes and its potential role in atherogenesis. Proc Natl Acad Sci U S A. 1988;85:2805-2809.

21. Duewell P, Kono H, Rayner KJ, Sirois CM, Vladimer G, Bauernfeind FG, Abela GS, Franchi L, Nunez G, Schnurr M, Espevik T, Lien E, Fitzgerald KA, Rock KL, Moore KJ, Wright SD, Hornung V, Latz E. NLRP3 inflammasomes are required for atherogenesis and activated by cholesterol crystals. Nature. 2010;464:1357-1361.

22. Park YS, Kim J, Misonou Y, Takamiya R, Takahashi M, Freeman MR, Taniguchi N. Acrolein induces cyclooxygenase- 2 and prostaglandin production in human umbilical vein endothelial cells: roles of p38 MAP kinase. Arterioscler Thromb Vasc Biol. 2007;27:1319-1325.

23. Gross S, Tilly P, Hentsch D, Vonesch JL, Fabre JE. Vascular wallproduced prostaglandin E2 exacerbates arterial thrombosis and atherothrombosis through platelet EP3 receptors. J Exp Med. 2007;204: 311-320.

24. Wang M, Zukas AM, Hui Y, Ricciotti E, Pure E, FitzGerald GA. Deletion of microsomal prostaglandin E synthase-1 augments prostacyclin and retards atherogenesis. Proc Natl Acad Sci U S A. 2006;103:14507-14512.

25. Samuelsson B, Morgenstern R, Jakobsson PJ. Membrane prostaglandin E synthase-1: a novel therapeutic target. Pharmacol Rev. 2007;59:207-224.

26. Schieffer B, Selle T, Hilfiker A, Hilfiker-Kleiner D, Grote K, Tietge UJ, Trautwein C, Luchtefeld M, Schmittkamp C, Heeneman S, Daemen MJ, Drexler H. Impact of interleukin-6 on plaque development and morphology in experimental atherosclerosis. Circulation. 2004;110: 3493-3500.

27. Luchtefeld M, Schunkert H, Stoll M, Selle T, Lorier R, Grote K, Sagebiel C, Jagavelu K, Tietge UJ, Assmus U, Streetz K, Hengstenberg C, Fischer M, Mayer B, Maresso K, El Mokhtari NE, Schreiber S, Muller W, Bavendiek U, Grothusen C, Drexler H, Trautwein C, Broeckel U, Schieffer B. Signal transducer of inflammation gp130 modulates atherosclerosis in mice and man. J Exp Med. 2007;204:1935-1944.

28. Kumar S, Boehm J, Lee JC. p38 MAP kinases: key signalling molecules as therapeutic targets for inflammatory diseases. Nat Rev Drug Discov. 2003;2:717-726.

29. Jing Q, Xin SM, Cheng ZJ, Zhang WB, Zhang R, Qin YW, Pei G. Activation of $\mathrm{p} 38$ mitogen-activated protein kinase by oxidized LDL in vascular smooth muscle cells: mediation via pertussis toxin-sensitive $G$ proteins and association with oxidized LDL-induced cytotoxicity. Circ Res. 1999;84:831-839.

30. Kusuhara M, Chait A, Cader A, Berk BC. Oxidized LDL stimulates mitogen-activated protein kinases in smooth muscle cells and macrophages. Arterioscler Thromb Vasc Biol. 1997;17:141-148.

31. Fredrikson GN, Andersson L, Soderberg I, Dimayuga P, Chyu KY, Shah PK, Nilsson J. Atheroprotective immunization with MDA-modified apo B-100 peptide sequences is associated with activation of Th2 specific antibody expression. Autoimmunity. 2005;38:171-179.

32. Fredrikson GN, Bjorkbacka H, Soderberg I, Ljungcrantz I, Nilsson J. Treatment with apo B peptide vaccines inhibits atherosclerosis in human apo B-100 transgenic mice without inducing an increase in peptidespecific antibodies. J Intern Med. 2008;264:563-570.

33. Fredrikson GN, Soderberg I, Lindholm M, Dimayuga P, Chyu KY, Shah $\mathrm{PK}$, Nilsson J. Inhibition of atherosclerosis in apoE-null mice by immunization with apoB-100 peptide sequences. Arterioscler Thromb Vasc Biol. 2003;23:879-884.

34. Segrest JP, Jones MK, De Loof H, Dashti N. Structure of apolipoprotein B-100 in low density lipoproteins. J Lipid Res. 2001;42:1346-1367.

35. Forgez P, Gregory H, Young JA, Knott T, Scott J, Chapman MJ. Identification of surface-exposed segments of apolipoprotein B-100 in the LDL particle. Biochem Biophys Res Commun. 1986;140:250-257.

36. Hakala JK, Oksjoki R, Laine P, Du H, Grabowski GA, Kovanen PT, Pentikainen MO. Lysosomal enzymes are released from cultured human macrophages, hydrolyze LDL in vitro, and are present extracellularly in human atherosclerotic lesions. Arterioscler Thromb Vasc Biol. 2003;23: $1430-1436$.

37. Oorni K, Sneck M, Bromme D, Pentikainen MO, Lindstedt KA, Mayranpaa $M$, Aitio H, Kovanen PT. Cysteine protease cathepsin $F$ is expressed in human atherosclerotic lesions, is secreted by cultured macrophages, and modifies low density lipoprotein particles in vitro. $J$ Biol Chem. 2004;279:34776-34784.

38. Jaffer FA, Kim DE, Quinti L, Tung CH, Aikawa E, Pande AN, Kohler RH, Shi GP, Libby P, Weissleder R. Optical visualization of cathepsin K 
activity in atherosclerosis with a novel, protease-activatable fluorescence sensor. Circulation. 2007;115:2292-2298.

39. Pepin JM, O'Neil JA, Hoff HF. Quantification of apo[a] and apoB in human atherosclerotic lesions. J Lipid Res. 1991;32: $317-327$.
40. Kruth HS, Shekhonin B. Evidence for loss of apo B from LDL in human atherosclerotic lesions: extracellular cholesteryl ester lipid particles lacking apo B. Atherosclerosis. 1994;105:227-234.

41. Matzinger P. The danger model: a renewed sense of self. Science. 2002; 296:301-305.

\section{CLINICAL PERSPECTIVE}

Accumulated low-density lipoprotein particles in arterial wall are the primary cause of atherosclerosis by triggering chronic vascular inflammation, characterized by local activation of cellular inflammatory responses including lesional macrophages. The molecular identities of low-density lipoprotein-derived inflammatory components have been poorly defined. Apolipoprotein B100 (ApoB100) is the only unchangeable protein constituent of the low-density lipoprotein particle. Both clinical and preclinical studies suggest that ApoB100 protein fragments are implicated in modulation of immune responses in the process of disease development, implying that ApoB100 is not a bystander to the inflammation of atherosclerosis. In the present study, by screening a peptide library of human ApoB100, we have identified a previously unrecognized native peptide fragment that exhibits distinctive activity triggering inflammatory responses of human monocytes/macrophages and atherosclerotic plaques ex vivo. Given its capacity to induce innate immune responses, we named the peptide ApoB100 danger-associated signal 1, signifying the first identified ApoB100-derived danger-associated signal. Importantly, the peptides with specific ApoB100 danger-associated signal 1 activity are present in atherosclerosis. These findings shed light on the pathobiological role of low-density lipoprotein in atherosclerosis. 


\section{SUPPLEMENTAL MATERIAL}

\section{Supplemental Methods}

\section{Synthetic ApoB100 peptides}

A library of synthetic peptides of human ApoB100 was used ${ }^{1}$. Briefly, 302 peptides that encompassed the entire sequence of human ApoB100 protein were synthesized (K.J. Ross Petersen AS, Denmark) and numbered consecutively from P1 to P302, starting from the N-terminus. Each peptide was 20 amino acids long, in each of which the first 5 amino acids overlapped with the C-terminal sequence of the previous peptide and the last 5 amino acids overlapped with the N-terminal sequence of the next peptide. A stock solution of the peptides was prepared with $10 \% \mathrm{EtOH}$ in aqueous $\mathrm{NaCl}(9 \mathrm{mg} / \mathrm{ml})$ or PBS. No thiobarbituric acid reactive substances (TBARS) were detected in the preparations. In addition, 3 truncated fragments of P216 (ApoBDS-1), referred to as P216a, P216b, and P216c, were synthesized and purified identically as peptide ApoBDS-1 (Ross Petersen AS, Denmark).

Endotoxin levels in the synthetic peptides never exceeded $50 \mathrm{pg} / \mathrm{mg}$ of peptide, as determined by Limulus amoebocyte lysate detection assay (Associates of Cape Cod, Inc., Woods Hole, MA, USA).

\section{Isolation and culture of human PBMCs}

Peripheral blood from healthy volunteers was obtained from the Blood Central of Karolinska University Hospital, Stockholm, Sweden. Peripheral blood mononuclear cells 
(PBMCs) were isolated using Lymphoprep ${ }^{\mathrm{TM}}$ gradient medium (density $1.077 \mathrm{~g} / \mathrm{ml}$; Axis-

Shield, Oslo, Norway) according to the manufacturer's instructions. The cells were cultured in RPMI that was supplemented with $10 \% \mathrm{FCS}$. After $24 \mathrm{~h}$ in culture, $2.5 \times 10^{5}$

PBMCs/well in RPMI with 1\% FCS were incubated with the indicated concentrations of ApoBDS- 1 for $24 \mathrm{~h}$ at $37^{\circ} \mathrm{C}, 5 \% \mathrm{CO}_{2}$.

\section{Macrophage differentiation in vitro}

PBMCs were cultured in RPMI that was supplemented with $10 \%$ FCS in a dish at $1.5 \times 10^{5}$ cells $/ \mathrm{cm}^{2}$. After a $1-\mathrm{h}$ adherence step, floating cells were discarded. Adherent monocytes were used to generate macrophages, as described ${ }^{2}$. Briefly, monocytes were cultured for 7 days in medium that contained $60 \%$ AIM V $^{\circledR}$ (Gibco Invitrogen, Carlsbad, CA, USA) and 30\% Iscove's Modified Dulbecco's Medium (IMDM, Gibco Invitrogen, Carlsbad, CA, USA) and was supplemented with $10 \%$ inactivated $\mathrm{AB}+$ serum on dishes. The media was changed after 3 days. After differentiation, the cells were scraped, resuspended in RPMI that was supplemented with 10\% FCS, and allowed to rest. After 24 $\mathrm{h}$ of rest, $2.5 \times 10^{5}$ macrophages $/ \mathrm{ml}$ were plated in RPMI with $1 \%$ FCS and incubated with $25 \mu \mathrm{g} / \mathrm{ml}$ ApoB-DS1 for $24 \mathrm{~h}$ at $37^{\circ} \mathrm{C}, 5 \% \mathrm{CO}_{2}$.

\section{Stable TLR4 transfectants}

HEK-293/TLR4 cells (stably transfected with human TLR4A, MD-2, and CD14, Invivogen, San Diego, CA, USA) were grown in DMEM with 10\% FCS, HygroGold ${ }^{\mathrm{TM}}$ (50 $\mu \mathrm{g} / \mathrm{ml})$, Normocin ${ }^{\mathrm{TM}}(100 \mu \mathrm{g} / \mathrm{ml})$, and blasticidin $(10 \mu \mathrm{g} / \mathrm{ml})$ and seeded at $1 \times 10^{4}$ cells per well. Cells were stimulated with LPS (100 ng/ml) or ApoBDS-1 $(50 \mu \mathrm{g} / \mathrm{ml})$ and incubated 
overnight at $37^{\circ} \mathrm{C}, 5 \% \mathrm{CO}_{2}$. IL-8 concentrations in the supernatants were measured by ELISA.

\section{Cytokine and chemokine measurements}

TNF- $\alpha$, IL-1 $\beta$, IL-6, IL-10, IL-12p40, IFN- $\gamma$, IP-10, MIG, IL-8, CCL2 (MCP-1), and CCL5 (RANTES) in the supernatants of PBMC and plaque tissue cultures were measured by Cytometric Bead Array $\left(\mathrm{CBA}^{\circledR}\right.$, BD Bioscience, CA, USA) or ELISA (R\&D Systems, Abingdon, United Kingdom), following the manufacturer's protocol. Prostaglandin E2 (PGE2) in the supernatants of PBMC and plaque tissue cultures was measured using the PGE2 Express EIA Kit (Cayman Europe, Tallin, Estonia) per the manufacturer's instructions.

\section{RNA analysis}

RNA extraction and reverse-transcription were performed as described ${ }^{3}$. Quantitative real time-PCR analysis was performed on an ABI Prism 7900 HT Sequence Detector (Applied Biosystems, Foster City, CA, USA) using Assay-on-Demand primers and probes (Applied Biosystems, Foster City, CA, USA). mRNA levels were normalized to the housekeeping genes $\beta-2$ macroglobulin and GAPDH. Relative expression was determined by the $2^{-\Delta \Delta \mathrm{CT}}$ method ${ }^{4}$.

\section{Analysis of calcium flux}

PBMCs were resuspended at $1 \times 10^{6}$ cells $/ \mathrm{ml}$ in Hanks' balanced saline solution (HBSS), containing calcium, 1\% (v/v) FCS, $5 \mu$ M Fluo-4 AM (Molecular Probes, Invitrogen, Carlsbad, CA, USA), and $2.5 \mathrm{mM}$ probenecid (Molecular Probes, Invitrogen, 
Carlsbad, CA, USA). After a 30 min pre-incubation at $37^{\circ} \mathrm{C}$, the cells were washed with calcium-free HBSS and incubated with $25 \mu \mathrm{g} / \mathrm{ml}$ ApoBDS-1 or $2.5 \mu \mathrm{M}$ calcium ionhophore as a positive control. Increased calcium flux was recorded within 240 seconds, as indicated in the figures. Samples were excited at $485 \mathrm{~nm}$, and emission spectra were recorded at 535 $\mathrm{nm}$ by fluorescence microscopy or on a 96-well plate fluorescence reader (Fluoroskan Ascent FL, Thermo Scientific). Data are presented as fold-increase compared with baseline readings from cells in medium alone.

\section{Detection of MAPK phosphorylation}

To examine MAPK responses, THP-1 cells were stimulated with $25 \mu \mathrm{g} / \mathrm{mL}$ ApoBDS-1 for the indicated times. Next, the cells were washed with cold PBS, and lysates were generated by homogenizing the cells in RIPA lysis buffer $\left(1 \%\right.$ Nonidet ${ }^{\circledR}$ P40, $50 \mathrm{mM}$ Tris, $\mathrm{pH} 8.0,150 \mathrm{mM} \mathrm{NaCl}$, deoxycholate $0,5 \%$, SDS $0.1 \%$ ) supplemented with protease inhibitor cocktail (Complete ${ }^{\mathrm{TM}}$, Roche, Basel, Switzerland) and phosphatase inhibitors (10 mM sodium fluoride and $1 \mathrm{mM}$ sodium orthovanadate, Sigma-Aldrich, St. Louis, MO, USA).

Equal amounts of proteins $(30 \mu \mathrm{g})$ were separated by SDS-PAGE $(4.0 \%-15 \%$, BioRad, Richmond, CA, USA) and transferred to a PVDF membrane (GE Healthcare, Uppsala, Sweden). After being blocked with 5\% nonfat dry milk, phosphorylated and total proteins were detected using monoclonal antibodies to ERK1/2, phospho-ERK1/2, p38, phosphop38, JNK, and phospho-JNK (Cell Signaling Technology, Beverly, MA, USA). The blots were incubated with HRP-conjugated anti-rabbit IgG (Dako, Glostrup, Denmark) and developed by ECL (GE Healthcare, Uppsala, Sweden). 


\section{Blocking of MAPK signaling pathways}

For pharmacological inhibition of ERK1/2, p38-MAPK, and JNK, PD98059 (10 $\mu \mathrm{M})$, SB203580 $(10 \mu \mathrm{M})$, and SP600125 (40 $\mu \mathrm{M})$ (all purchased from Calbiochem, Darmstadt, Germany) were added 30 min before the PBMCs were stimulated with peptides. The inhibitors were dissolved in 100\% dimethylsulphoxide (DMSO); the final concentration of DMSO in the cultures was $<0.1 \%$. Unstimulated cell cultures that were incubated with $0.1 \%$ DMSO were included as a control and did not experience any biological effects (data not shown).

\section{Anti-ApoBDS-1 specificity analysis.}

Specificity of anti-ApoBDS-1 rabbit polyclonal IgG antibody against ApoBDS-1 was evaluated by ELISA. Briefly, $50 \mu \mathrm{L}$ of the different antigens $(1 \mu \mathrm{g} / \mathrm{ml}$ in Carbonate/Bicarbonate $\mathrm{pH}$ 9.5) was added to 96-well ELISA plates and incubated overnight at $4^{\circ} \mathrm{C}$. Coated plates were washed with PBS and blocked with $1 \%$ gelatin (Gibco Invitrogen, Carlsbad, CA, USA) in PBS for $1 \mathrm{hr}$ at room temperature. Next, plates were washed and incubated for 2 additional hours with anti-ApoBDS-1 antibody diluted 1:1000 in Tris-buffered saline (TBS)/gelatin 0.1\%. After washing, total IgG levels were measured using enzyme-conjugated goat anti-rabbit antibodies (Dako, Glostrup, Denmark). The plates were washed, and colorimetric reactions were developed using TMB (3,3',5, '’Tetramethylbenzidine, BD Biosciences, Franklin Lakes, NJ, USA). The absorbance was measured using a microplate reader (VersaMax, Molecular Devices, Sunnyvale, CA, USA). 


\section{Supplemental Figures}

\section{Supplemental figure I}

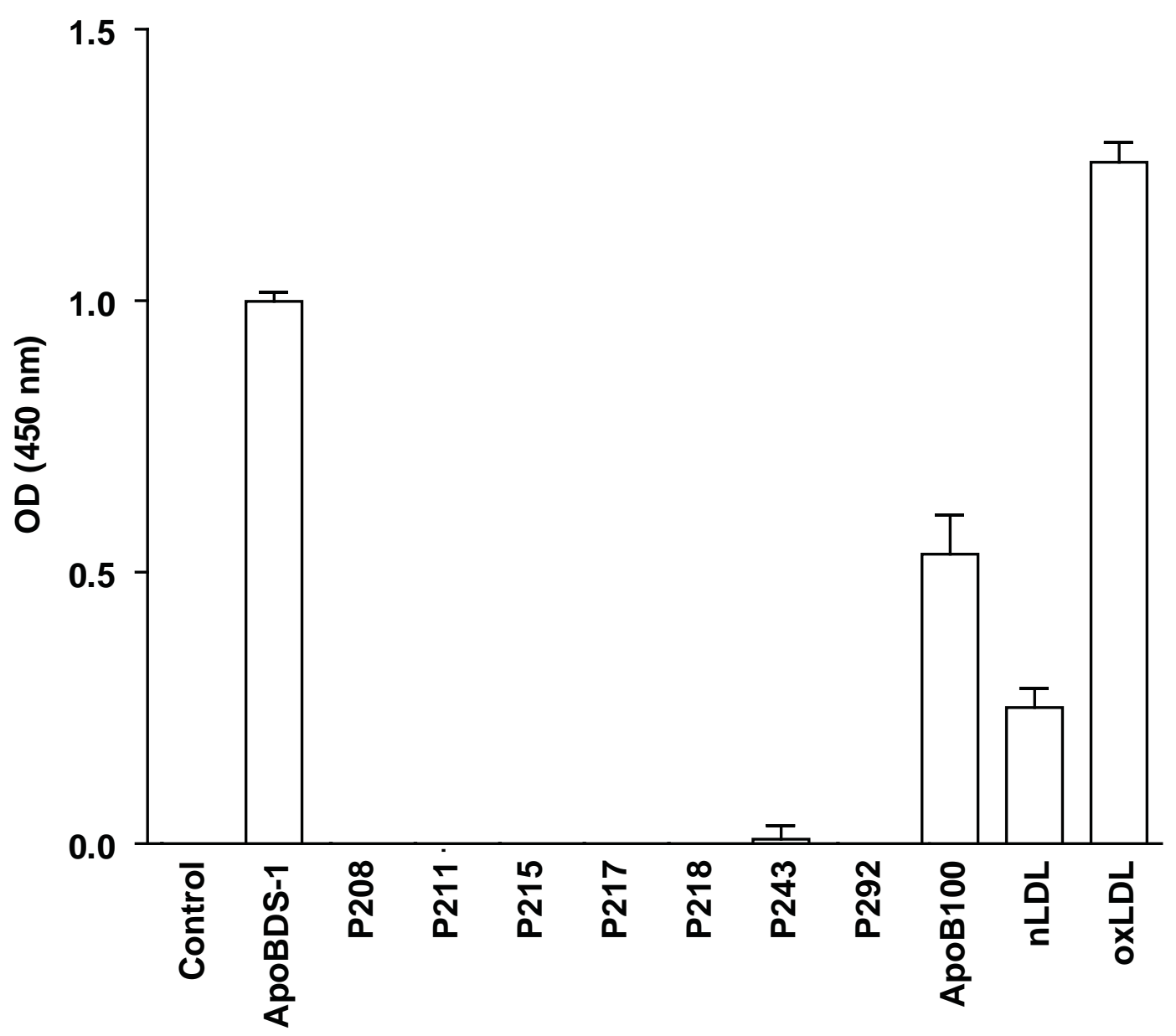




\section{Supplemental figure II}

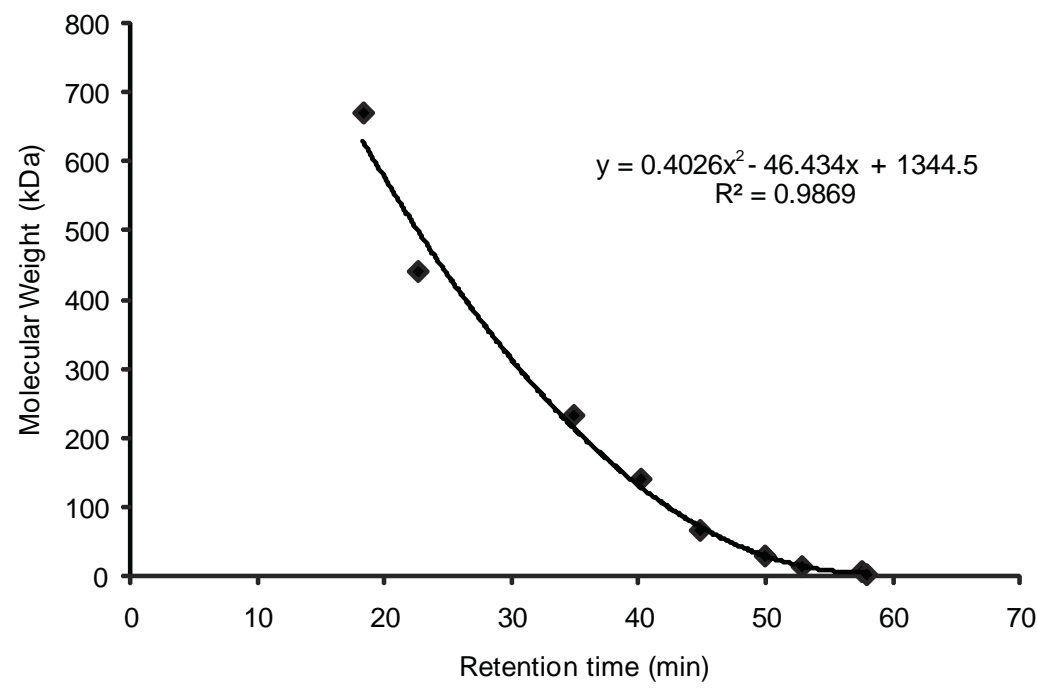


Supplemental figure III

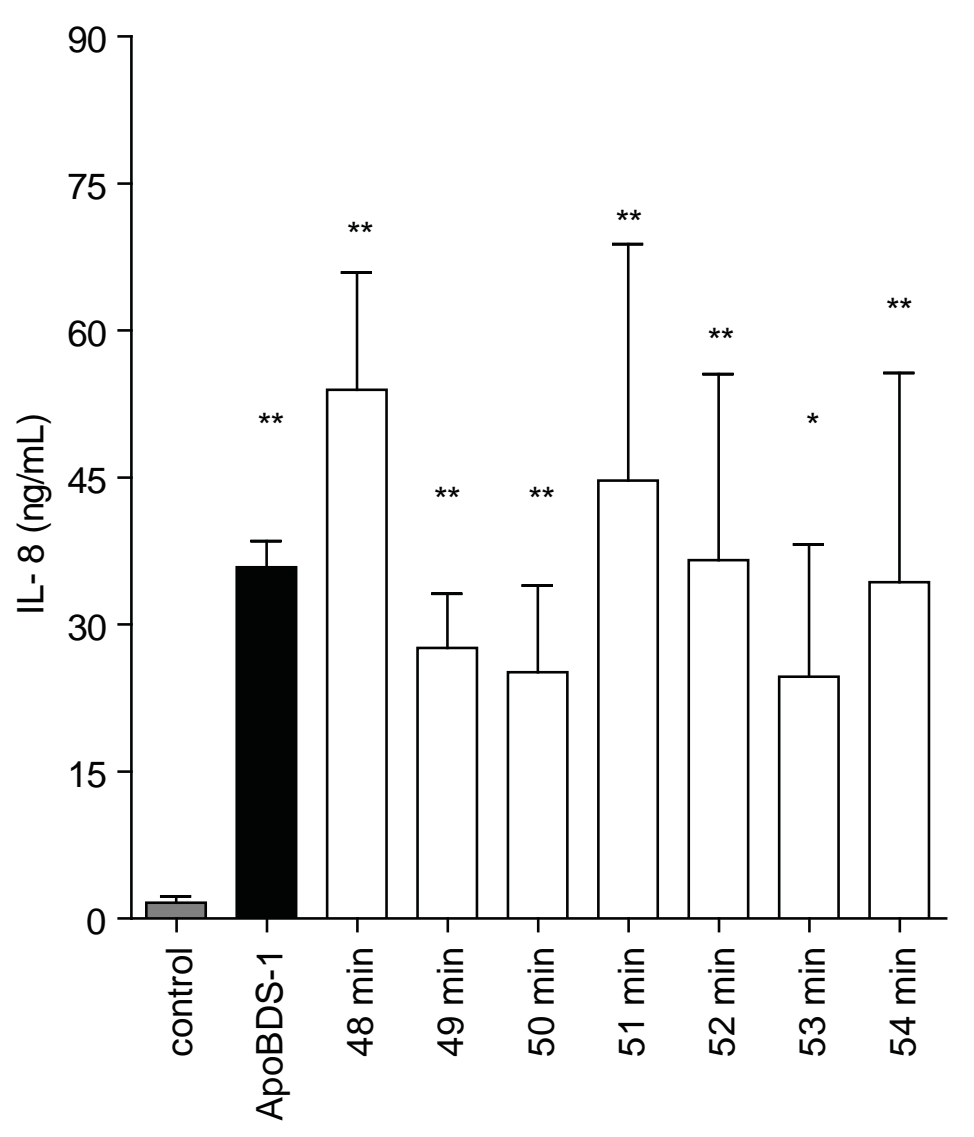




\section{Supplemental figure IV}

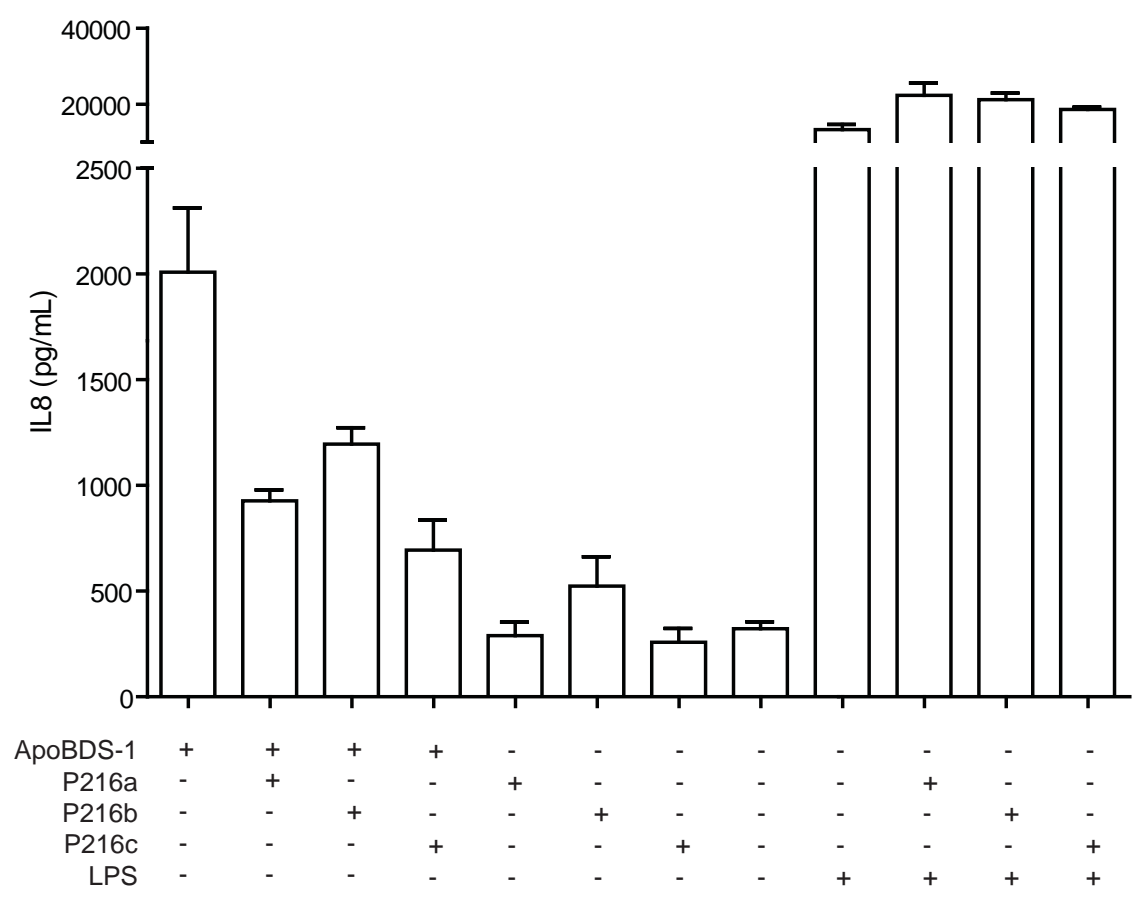




\section{Supplemental figure legends}

\section{Supplemental figure I. Anti-ApoBDS-1 antibody specificity analysis.}

Specific reactivity of anti-ApoBDS-1 rabbit polyclonal IgG antibody to the ApoB100 peptides, ApoB100 protein, native LDL, and oxLDL was evaluated by ELISA. Values are expressed as mean $\pm \mathrm{SEM}$ of the $\mathrm{OD}$ at $450 \mathrm{~nm}$.

\section{Supplemental figure II. Molecular weight calibration of Superose 6/Discovery BIO GFC-500.}

Molecular weight calibration of the coupled columns Superose 6 and Discovery BIO GFC500 was performed using LMW and HMW protein cocktails from GE Healthcare, Uppsala, Sweden. Samples fractionated at a flow rate of $0.4 \mathrm{~mL} / \mathrm{min}$, using Ammonium bicarbonate buffer, pH 7.4. Thyroglobulin 669 kDa; Ferritin 440 kDa; Catalase 232 kDa; Lactate dehydrogenase 140 kDa; Albumin 66 kDa; Carbonic Anhydrase 29 kDa; Ribonuclease A 13.7 kDa; Aprotinin $6.5 \mathrm{kDa}$. $\mathrm{X}$ axis, retention time; $\mathrm{Y}$ axis, molecular weight $(\mathrm{kDa})$.

\footnotetext{
Supplemental figure III. Assessment of IL-8 production in response to low molecular weight ApoBDS-1 positive fractions from plaque homogenates.

$2 \times 10^{5}$ PBMCs were stimulated with low molecular weight fractions (10 to $42 \mathrm{kDa}$ ) from 2 different plaque homogenates. ApoBDS-1 (50 $\mu \mathrm{g} / \mathrm{ml})$ was used as positive control (black bar), and medium alone as negative control (grey bar). IL-8 was measured after $24 \mathrm{~h}$. Data are means \pm SEM of IL-8 levels of 4 experiments. *) $\mathrm{P}<0.05 ; * *) \mathrm{P}<0.01$ for samples vs negative control.
} 
Supplemental figure IV. Blockade of ApoBDS-1 induced IL-8 release from PBMCs by truncated ApoBDS-1 peptides.

$2 \times 10^{5}$ PBMCs were stimulated with ApoBDS-1 $(25 \mu \mathrm{g} / \mathrm{ml})$ or in combination with 5-fold molar excess of truncated ApoBDS-1 peptides P216a, P216b, or P216c. LPS (100 ng/ml) was used as positive control, and medium as negative control. IL-8 was measured after $24 \mathrm{~h}$ incubation. Truncated peptides are able to specifically block ApoBDS-1 induced IL-8 release. Data are presented as means \pm SEM of IL- 8 levels. *) $\mathrm{P}<0.05$. The data are representative of 2 experiments. 


\section{Supplemental References}

1. Fredrikson GN, Hedblad B, Berglund G, Alm R, Ares M, Cercek B, Chyu KY, Shah PK, Nilsson J. Identification of immune responses against aldehyde-modified peptide sequences in apoB associated with cardiovascular disease. Arterioscler Thromb Vasc Biol. 2003; 23: 872-878.

2. Gredmark S, Britt WB, Xie X, Lindbom L, Soderberg-Naucler C. Human cytomegalovirus induces inhibition of macrophage differentiation by binding to human aminopeptidase N/CD13. J Immunol. 2004; 173: 4897-4907.

3. Edfeldt K, Bennet AM, Eriksson P, Frostegard J, Wiman B, Hamsten A, Hansson GK, de Faire U, Yan ZQ. Association of hypo-responsive toll-like receptor 4 variants with risk of myocardial infarction. Eur Heart J. 2004; 25: 1447-1453.

4. Livak KJ, Schmittgen TD. Analysis of relative gene expression data using real-time quantitative PCR and the 2(-Delta Delta C(T)) Method. Methods (San Diego, Calif. 2001; 25: 402-408. 